\title{
Mongolia: Second Review Under the Stand-By Arrangement and Request for Modification of Performance Criteria
}

The following documents have been released and are included in this package:

- $\quad$ The staff report prepared by a staff team of the IMF, following discussions that ended on August 14, 2009, with the officials of Mongolia on economic developments and policies. Based on information available at the time of these discussions, the staff report was completed on September 3, 2009. The views expressed in the staff report are those of the staff team and do not necessarily reflect the views of the Executive Board of the IMF.

- $\quad$ A Press Release

- $\quad$ A statement by the Executive Director for Mongolia.

The documents listed below have been or will be separately released.

Letter of Intent sent to the IMF by the authorities of Mongolia* Memorandum of Economic Policies by the authorities of Mongolia* Technical Memorandum of Understanding*

*Also included in Staff Report

The policy of publication of staff reports and other documents allows for the deletion of market-sensitive information.

\author{
Copies of this report are available to the public from \\ International Monetary Fund $\bullet$ Publication Services \\ $70019^{\text {th }}$ Street, N.W. $\bullet$ Washington, D.C. 20431 \\ Telephone: (202) 623-7430 • Telefax: (202) 623-7201 \\ E-mail: publications@imf.org Internet: http://www.imf.org
}

\section{International Monetary Fund Washington, D.C.}




\section{INTERNATIONAL MONETARY FUND}

\section{MONGOLIA}

\section{Second Review Under the Stand-By Arrangement and Request for Modification of Performance Criteria}

Prepared by the Asia and Pacific Department in Consultation with Other Departments

Approved by Nigel Chalk and Anthony R. Boote

September 3, 2009

Stand-By Arrangement: A 18-month Stand-By Arrangement in the amount of SDR 153.3 million (300 percent of quota) was approved by the Executive Board (Country Report No. 09/130) on April 1, 2009, and a first purchase of SDR 51.1 million was made following the Board meeting. The first review was approved by the Executive Board on June 23, 2009, and a second purchase of SDR 25.55 million was made following the Board meeting. All end-June performance criteria for the second review were met.

Summary: The authorities' strong policy implementation under the program is working to stabilize market conditions and lower inflation. The central bank's foreign exchange auctions are working well and the authorities have renewed their commitment to allow the exchange rate to move flexibly, in line with market conditions. Monetary policy has been managed to steadily bring down inflation and rebuild international reserves. The economic recovery, however, is somewhat slower than foreseen at the time the program was approved. As a result, to provide greater support to the economy, fiscal policy is being eased modestly. At the same time, the authorities are fully committed to restoring health to public finances and will pass a Fiscal Responsibility Law by end-year. To protect the poor from the weaker economic outlook, the social transfer system is being reformed to improve targeting and provide greater support for the society's most vulnerable citizens. The economic slowdown has weakened credit quality and the authorities are monitoring the financial system closely and stand ready to take actions, as needed, to secure stability and bolster confidence in the banking system.

Discussions: A staff team visited Ulaanbaatar, August 3-14, 2009 consisting of S. Barnett (Head), J. Bersch, T. Feridhanusetyawan (APD), J. Hartley (SPR), J. Gottschalk (FAD), I. W. Song (MCM), and P. Ramlogan (Resident Representative). Mr. Moon (OED) joined the second week of discussions. The team held discussions with the Speaker of the Parliament, the Finance Minister, the Governor of the Bank of Mongolia, Minister of Mineral Resources and Energy, commercial banks, and other officials. The mission coincided with a technical assistance mission from MCM on developing a strategy for banking system reform. 


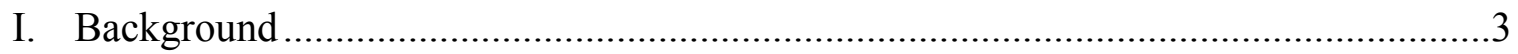

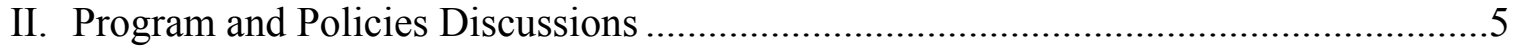

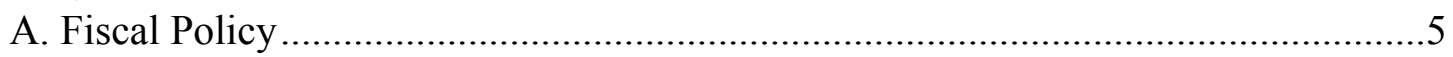

B. Monetary and Exchange Rate Policies................................................................6

C. Banking Sector Issues ...................................................................................

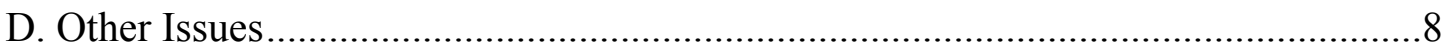

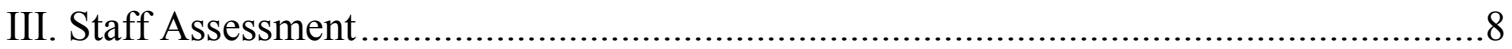

Box

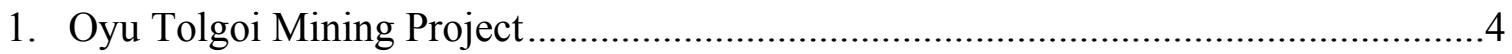

Figures

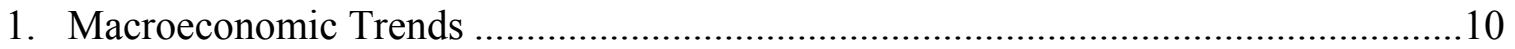

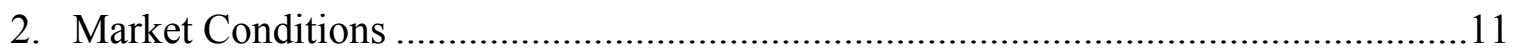

Tables

1. Selected Economic and Financial Indicators, 2007-10 …..........................................12

2. Summary Operations of the General Government, 2007-10.....................................13

3. Monetary Aggregates, 2007-10 ............................................................................14

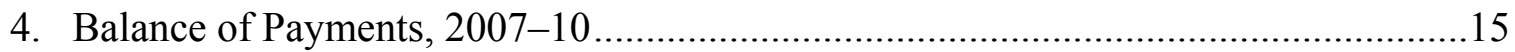

5. Reviews and Disbursements under the 18-Month Stand-by Arrangement..................16

Attachment

1. Letter of Intent, Memorandum of Economic Policies, and Technical Memorandum of

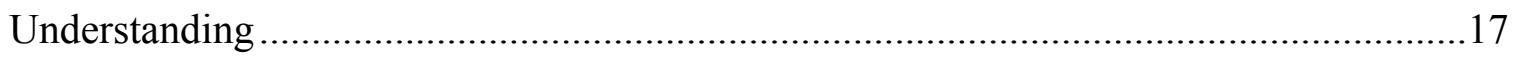




\section{BACKGROUND}

1. Context. The economy is slowing more-than-expected, growing only $3 / 4$ percent in the second quarter. Higher frequency data indicate industrial production is weak, both imports and nonmineral exports are declining sharply, and private sector credit is moribund (Figure 1). The macroeconomic framework has been revised with growth now at $1 / 2$ percent for this year, recovering to 3 percent in 2010. Copper prices,

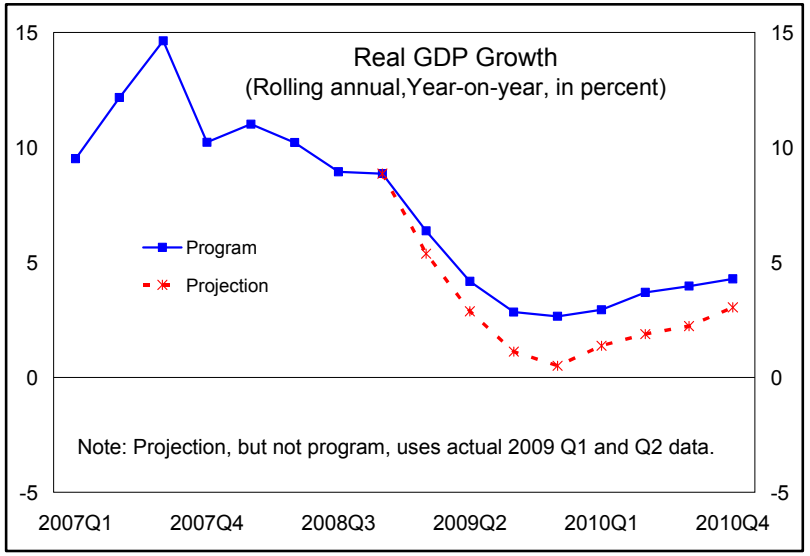
however, are considerably higher than previously assumed and negotiations for a large mining project are advancing (Box 1); both these factors provide some upside potential to the outlook.

2. Fiscal developments. Revenue continues to be weak, largely due to falling taxes on imports. The government also lowered the petroleum excise tax in July to mitigate the impact of higher energy prices, which would have an annual revenue loss of around $1 / 2$ percent of GDP. On the other hand, copper prices are considerably higher than originally envisaged under the program. The government has restrained spending to remain within program targets although the budget was amended to ensure that social transfer spending is protected and that existing social programs will be maintained for the rest of this year.

3. Monetary developments. The authorities have gradually eased monetary conditions. In mid-June, the policy rate was lowered 125 basis points which led to a corresponding reduction in interest rates along the yield curve. However, lower policy rates are doing little to expand private credit and there is scant evidence that the credit channel is working. At the same time, the authorities have been intervening to sell U.S. dollars, short circuiting the ability of looser monetary conditions to feed through to the economy via the exchange rate channel. Overall inflation has declined substantially, to 3 percent in July, but nonfood inflation has declined more slowly.

4. Banking. New banking and central bank laws were submitted to parliament in July (an end-June structural benchmark) with a slight delay due to the drafting of a new law (rather than amending the existing law as originally planned). The central bank has received capital reinforcement plans from all banks that are below the regulatory minimum, has identified potential problem banks, and is formulating a supervisory enforcement plan with USAID assistance. At the same time, the central bank has increased the number of on-site examiners and intensified off-site monitoring with assistance from the Japan International Cooperation Agency (JICA) (paragraph 6 of the Memorandum of Economic Policies (MEP)). 


\section{Box 1. Oyu Tolgoi Mining Project}

Oyu Tolgoi will be a key driver of the Mongolian economy. Development spending will boost growth in the short run, and in the long run the mining output will be a major source of export earnings and fiscal revenue. The copper and gold deposits are under development by Ivanhoe Mines Mongolia Inc., a joint venture between Ivanhoe Mines Ltd (Canadian) and Rio Tinto PLC (British). Negotiations of the investment agreement with the Mongolian government have been under way for several years and could be concluded in the near future. The Oyu Tolgoi investment agreement is expected to set a benchmark for several other mineral resource exploitation projects planned or under way.

The Oyu Tolgoi deposits are

massive. At peak capacity, copper production at the mine could account for 6 percent of world production. Staff project annual production to peak in 2019 at approximately 900,000 tons of copper and 50 tons of gold. Corresponding export revenues could approach 55 percent of GDP with government revenue reaching 20 percent of GDP.

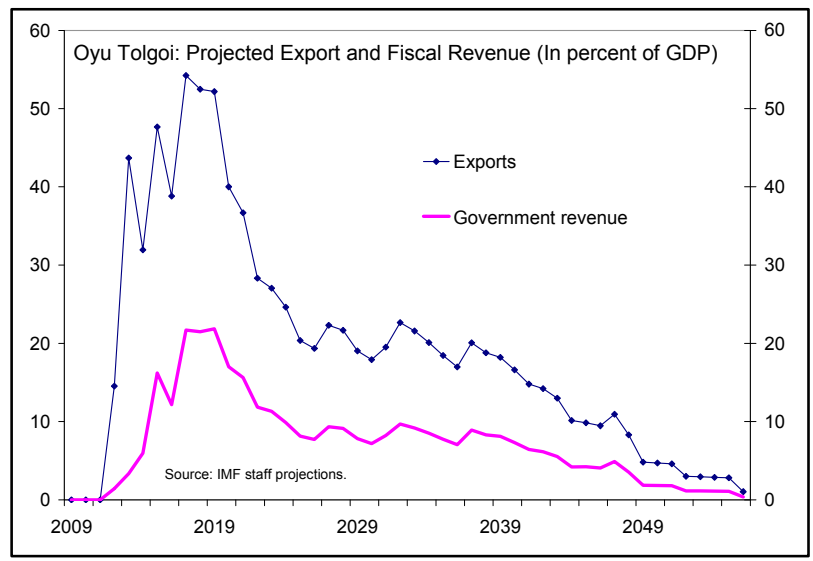

Development will lead to substantial FDI and job creation. Ivanhoe conducted exploratory work and shaft development between 2001 and 2007, and received mining licenses for Oyu Tolgoi in 2003. So far, US\$1 billion have been invested and an additional US\$4 billion could be invested over the next five years. Much of the FDI, however, could leak out via higher imports. Resumption of the development work at the Oyu Tolgoi deposits could immediately create around 1,000 jobs, increasing to 5,000 during construction, and stabilizing at 4,000 during operation. Secondary employment effects would also be large.

Production is still a few years away. It could start within three years of resumption of development and will proceed in two stages - first, an open-pit mine, followed some years later by an underground mine. Based on existing registered reserves, the initial life of the mine is expected to be 45 years. Significant extensions to mine life or increases in annual production are likely from adjacent ore resources within the existing license areas. The mine, however, is a complex and risky project in terms of technological feasibility, and there is considerable uncertainty regarding production during the first 10 to 15 years. 
5. Program performance. All end-June performance criteria for the second review were met. The authorities have also implemented all but two of the end-June structural benchmarks, albeit with some delay. The creation of a screen-based system for interbank foreign exchange transactions has not been completed. However, the foreign exchange auction system established under the program is working well and, while the authorities are moving ahead with a new electronic system for interbank transactions, staff proposes that the structural benchmark not be reset as it is no longer macro critical. Regarding Anod bank, a foreign investor recently expressed interest in buying the bank and the authorities plan to undertake a due diligence review of the potential purchaser and therefore delay an announcement of a resolution plan to end-October (paragraph 7, MEP).

\section{Program and Policy Discussions}

\section{A. Fiscal Policy}

6. Fiscal context. Fiscal revenue is projected to increase substantially as the Oyu Tolgoi mine gets up to capacity. In the interim, however, fiscal policy is constrained by the limited availability of financing. This is a direct product of the pro-cyclical policies of the past. Compared to the pre-boom averages, the nonmineral balance had worsened by some 10 percent of GDP due to reductions in the VAT rate, lower social security contributions, large increases in civil service wages, and a rapid expansion of untargeted social transfers. There was broad agreement that restoring fiscal sustainability should continue to be a central priority of the program.

Mongolia: Fiscal Indicators

(In percent of nonmineral GDP)

\begin{tabular}{|c|c|c|c|c|c|c|c|c|}
\hline & \multirow[b]{2}{*}{2006} & \multirow[b]{2}{*}{2007} & \multirow{2}{*}{$\begin{array}{l}\text { Rev. } \\
2008 \\
\end{array}$} & \multicolumn{2}{|c|}{ Proj. } & \multicolumn{3}{|c|}{ IMF CR/09/130 } \\
\hline & & & & 2009 & 2010 & 2008 & 2009 & 2010 \\
\hline Overall balance (in percent of GDP) & 8.2 & 2.8 & -4.8 & -6.5 & -5.0 & -5.0 & -6.0 & -4.0 \\
\hline Nonmineral balance & -3.2 & -14.9 & -20.6 & -15.7 & -11.6 & -20.9 & -12.2 & -11.3 \\
\hline Nonmineral revenue & 37.3 & 38.7 & 35.2 & 32.5 & 33.6 & 34.7 & 33.4 & 32.9 \\
\hline Total expenditure & 40.5 & 53.6 & 55.7 & 48.1 & 45.2 & 55.6 & 45.6 & 44.2 \\
\hline Cyclically adjusted nonmineral balance $1 /$ & -2.0 & -15.8 & -23.6 & -15.1 & -9.6 & -24.1 & -13.1 & -11.3 \\
\hline Fiscal effort (change in cyclically adjusted) & -1.7 & -13.8 & -7.8 & 8.5 & 5.5 & 0.0 & 11.0 & 1.8 \\
\hline Real expenditure growth & 25.8 & 48.5 & 15.4 & -13.2 & -2.8 & 15.2 & -15.3 & 1.7 \\
\hline Memorandum items: & & & & & & & & \\
\hline Real nonmineral GDP (growth in percent) & 9.2 & 12.2 & 11.0 & 0.6 & 3.5 & 11.0 & 3.2 & 5.0 \\
\hline Output gap of nonmineral GDP & -2.9 & 1.8 & 5.5 & -1.1 & -4.4 & 5.8 & 1.8 & 0.0 \\
\hline
\end{tabular}

Sources: Mongolian authorities; and IMF staff calculations.

$1 /$ In percent of potential nonmineral GDP. The elasticity assumptions are 1 for revenue and 0 for spending.

7. Deficit targets. To provide support to the economy in light of the larger-thanexpected output gap, the overall balance targets were loosened to a deficit of $6 \frac{1}{2}$ percent of GDP for this year and 5 percent of GDP for 2010 (paragraph 2, MEP). This will allow automatic stabilizers to operate and smooth the adjustment path although, over the course of 
this year and next, the policy effort in terms of the cyclically adjusted nonmineral balance is somewhat larger (see text table). For 2010, the authorities will achieve the needed adjustment by reforming social transfers (see below), reversing the recent reduction in fuel excises, freezing the nominal wage bill, and raising social security contributions. Passage of a budget in line with the program will be a structural benchmark for December 1, 2009.

8. Financing. For 2009 and 2010, additional fiscal financing will be provided from a slightly slower pace of accumulation of international reserves - by around US\$30 million each year - and, given the slower demand for private credit seen so far this year, a reallocation of bank lending from the private to public sector. Under the SDR allocations Mongolia will receive US\$75 million to bolster gross reserves. As a result, despite the additional resources being deployed to finance a larger fiscal deficit, by end-2010 gross reserves will be at broadly the same level assumed under the original program.

9. Structural fiscal reform. The authorities are pursuing structural reforms that will bolster fiscal credibility and lead to lasting improvements in public finances. Passage of a comprehensive social transfer reform this year (structural benchmark) - designed in collaboration with the World Bank and the Asian Development Bank-will generate fiscal savings through efficiency gains and safeguard the poor through better targeting. Key elements are a consolidation in the number of social benefits (from over 60 to less than 20), a reduction in untargeted universal transfers, and the introduction of a new benefit for those in poverty. The authorities are also in the midst of preparing a new Fiscal Responsibility Law (end-year structural benchmark) and an organic budget law, both supported by FAD technical assistance. These laws are expected to be effective starting with the 2011 budget. The Fiscal Responsibility Law is being drafted with a focus on numerical targets to ensure sustainability and reduce procyclicality, and procedural reforms to strengthen budget discipline.

\section{B. Monetary and Exchange Rate Policies}

10. Monetary policy. There was broad agreement that monetary policy should switch to a neutral bias and that further interest rate cuts, at this stage, are unlikely to provide much support for the real sector. Private credit growth has been sluggish, despite past reductions in the policy rate, and retail lending rates have adjusted little despite the banks appearing to have ample liquidity. Concerns over future credit quality are constraining banks' willingness to lend and the slow economy is lessening the demand for credit. Moreover, the central bank noted that much of the decline in inflation to date has been due to lower food prices and that nonfood inflation was declining more slowly and is still in the double-digits. As such, there was a common view that monetary policy needs to be cautious at this stage in the cycle and that the primary objectives of monetary policy should continue to be to steadily bring down inflation and rebuild international reserves.

11. Exchange rate policy. Staff continued to emphasize the importance of better coordinating monetary and exchange rate policy. The recent loosening of monetary conditions has, as would be expected, added to downward pressure on the exchange rate from 
seasonally high demand for foreign currency. However, in July, the central bank resisted this downward pressure by selling U.S. dollars and maintaining the rate within a narrow band. There was agreement that, going forward, intervention should be used more sparingly and geared towards avoiding large day-to-day movements in the exchange rate while opportunistically building international reserves. If downward pressures on the exchange rate intensify, the central bank agreed that it would adjust interest rates to ensure that program reserve targets are achieved and that market stability is

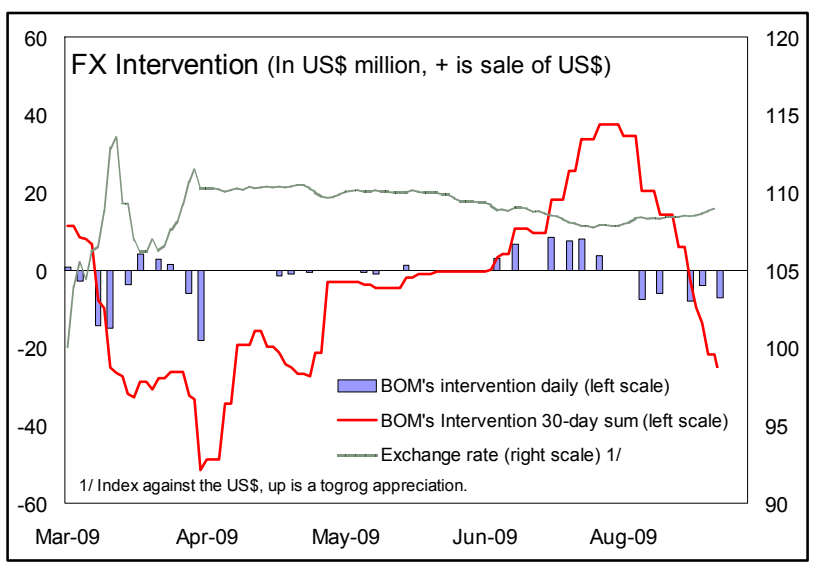
maintained. The authorities noted that the twice-weekly foreign exchange auctions have been working well and will be maintained for the time being. At the same time, the central bank is moving to strengthen the interbank foreign exchange market, including by developing the existing screen-based system to serve as the main trading platform for interbank transactions.

\section{Banking Sector Issues}

12. Anod bank. Recently, a foreign investor expressed interest in buying the bank and the authorities plan to delay an announcement of a resolution while they undertake a due diligence review of the potential purchaser. Any costs associated with the resolution would be fiscalized through an issuance of government bonds by the end of the year (paragraph 7 , MEP). The benchmark was initially delayed due to concerns that minority shareholders may sue the government. Staff emphasized that linking the resolution to concerns over possible lawsuits could set a risky and potentially costly precedent, and that resolution should proceed as quickly as possible and any lawsuits should be handled separately through the existing legal system.

13. Systemic bank restructuring. Asset quality across the system now appears weaker than official indicators would suggest. The three largest banks have around 60 percent of the market and exceed the minimum 12 percent capital adequacy ratio by some 2 percentage points. System wide, however, there are a large amount of restructured loans that, under the existing classification system, are considered performing assets. The central bank, therefore, has been seeking international assistance to develop a broader and more proactive restructuring scheme and, in conjunction with MCM, staff will discuss steps to improve loan classification during the next review. With the support of the World Bank, the authorities plan to have external audits of all banks in order to provide a clearer picture of the existing situation. In addition, an overlapping MCM TA mission examined the need for and potential costs of bank restructuring, including through comprehensive stress testing. Staff emphasized that any restructuring or recapitalization plan will need to be accompanied by governance and structural reforms to strengthen the banks, such as changes in management and senior 
staff, enhancing internal control and risk management, preparing operational restructuring plans to cut costs and improve revenue, and implementing efficient NPL resolution.

14. Banking supervision. The authorities continue to closely monitor the handful of small and mid-sized banks that do not comply with prudential norms, and have tightened their supervision of these institutions. Staff advised that stronger enforcement measures should be considered. The central bank indicated that they would prefer to deal with these banks - which together represent around 20 percent of system assets - as part of a comprehensive reform strategy. Their concern was that any early enforcement action against these institutions could risk destabilizing the system as a whole. However, in the event that any of these banks face severe stress in the near future, including through deposit outflows, the central bank emphasized it will act promptly to contain any such problems.

\section{Other Issues}

15. External financing. The authorities are negotiating a swap arrangement with China that could be signed in the near future and the Article VIII concerns discussed in the last staff report have been resolved. ${ }^{1}$ It was agreed, however, that the authorities should proceed cautiously with regards to further nonconcessional external borrowing and the government would keep in place the current prohibition on government guarantees. Regarding the external borrowing of US\$75 million that has been on-lent to gold mines, the authorities remain committed to having these loans repaid to the budget by the end of the year.

16. Program issues. The authorities are following up on the recommendations of the safeguards assessment and are working to reach agreement on their outstanding arrears to bilateral creditors (paragraph 10, MEP). The mission also briefed the authorities on the reforms to the IMF's lending infrastructure for low-income countries and their relevance for Mongolia, as well as the implications of the recent SDR allocations.

\section{Staff ASSESSMent}

17. Overview. The authorities' success in again meeting all of the program's quantitative targets is commendable. Their program, moreover, is working well to stabilize market conditions and lower inflation. The external shock, however, is having a stronger than foreseen impact on the economy, and targets have been recalibrated to reflect the revised growth outlook. The revised targets balance the need for continued economic adjustment with that of supporting growth through some easing of fiscal policy. The slowing economy, moreover, is taking its toll on the banks and strengthening the financial system remains a priority for the period ahead.

\footnotetext{
${ }^{1}$ The program counts any drawings under the swap arrangement toward the ceiling on long-term nonconcessional borrowing.
} 
18. Fiscal policy. The authorities' fiscal restraint is welcome, and a continuation of this discipline will ensure they meet their deficit targets. The 2010 budget is ambitious and the needed adjustment will be achieved through better quality measures than that which underpinned the 2009 fiscal program. In particular, the planned comprehensive social transfer reform is an important step forward that will generate fiscal saving, protect the poor, and yield a lasting improvement in public finances. The social transfer reform and wage restraint in 2010 are in line with recommendations from FAD technical assistance, and there is scope for future savings by better prioritizing investment spending and reforming subsidies. The planned adoption of a Fiscal Responsibility Law and an organic budget law will promote prudent fiscal management and help contain procyclicality.

19. Monetary and exchange rate policy. The program's quantitative targets provide a clear framework for the conduct of monetary and exchange rate policy. Foreign currency intervention should be limited and the exchange rate should be allowed to move flexibly in line with market conditions. This will lay the foundation for macroeconomic stability and low inflation going forward.

20. Banking system. The slowing economy is putting additional stress on the banking system, and the central bank should monitor the situation closely and implement enforcement measures against those banks that fail to conform to prudential regulations. It is critical that any public financial support to banks be tied to governance and structural reforms in order to strengthen future prospects for the system as a whole.

21. Risks. The authorities' strong program implementation is helping to reduce risks on many dimensions but the weaker-than-expected economic activity is providing a new source of pressure. Managing the existing and prospective weakness in the banking system will be challenging, and could require difficult decisions to be made in the coming months. Meeting the targets for international reserve accumulation will require net foreign exchange purchases by the central bank, which may lead to some exchange rate depreciation. Should market pressures return, interest rates may need to move higher. Finally, the fiscal adjustment remains ambitious and steadfast expenditure restraint will be needed to achieve the fiscal targets for this year and next.

22. The Mongolian authorities' strong performance so far under the program is encouraging, and their revised program remains ambitious. Staff recommends the approval of the second review. 


\section{Figure 1. Macroeconomic Trends}

Main Message: High frequency data suggest the economy is slowing more than expected, with weakness evident across a range of supply and demand side indicators.

Industrial production and real GDP have fallen more sharply than expected.

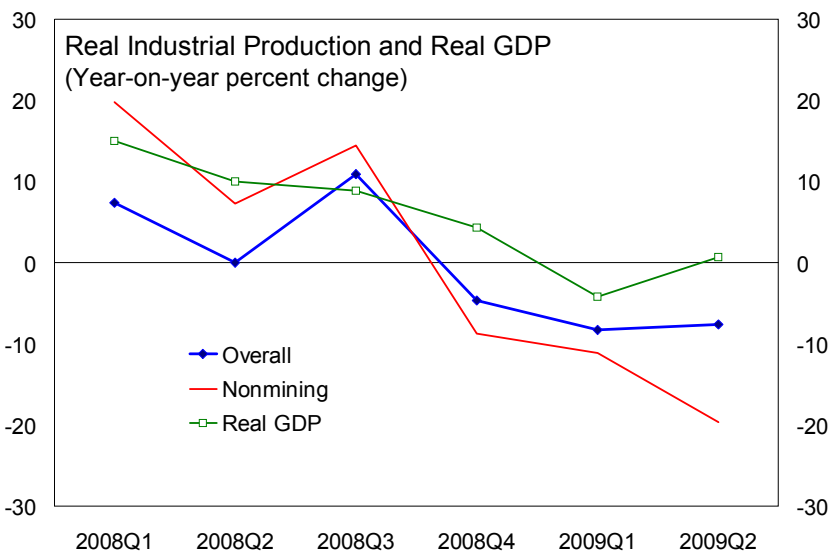

Trade is slowing significantly, reflecting weak domestic and external demand (as well as commodity price declines).

Mongolia: Trade Indicators

\begin{tabular}{lcccc}
\hline & 2008 & \multicolumn{2}{c}{$\begin{array}{c}\text { Growth rate } \\
\text { (year-on-year) }\end{array}$} & $\begin{array}{c}\text { Contr. to import and } \\
\text { export growth, resp. }\end{array}$ \\
\cline { 3 - 4 } & in US\$ million & 2008 & $2009 \mathrm{H} 1$ & $2009 \mathrm{H} 1$ \\
\hline Imports & 3,245 & 57 & -39 & -39 \\
$\quad$ Oil and minerals & 964 & 60 & -53 & -15 \\
Machinery and equipment & 606 & 43 & -31 & -6 \\
Transport vehicles & 459 & 106 & -25 & -4 \\
Base metals & 267 & 63 & -61 & -5 \\
Other & 948 & 46 & -31 & -9 \\
Exports & & & & \\
$\quad$ Minerals incl. precious metal & 2,534 & 30 & -40 & -40 \\
Nonmineral & 2,130 & 39 & -43 & -37 \\
& 405 & -2 & -20 & -3 \\
\hline
\end{tabular}

Slowing growth and macro policies are helping to drive down inflation, but nonfood inflation remains in the double digits.

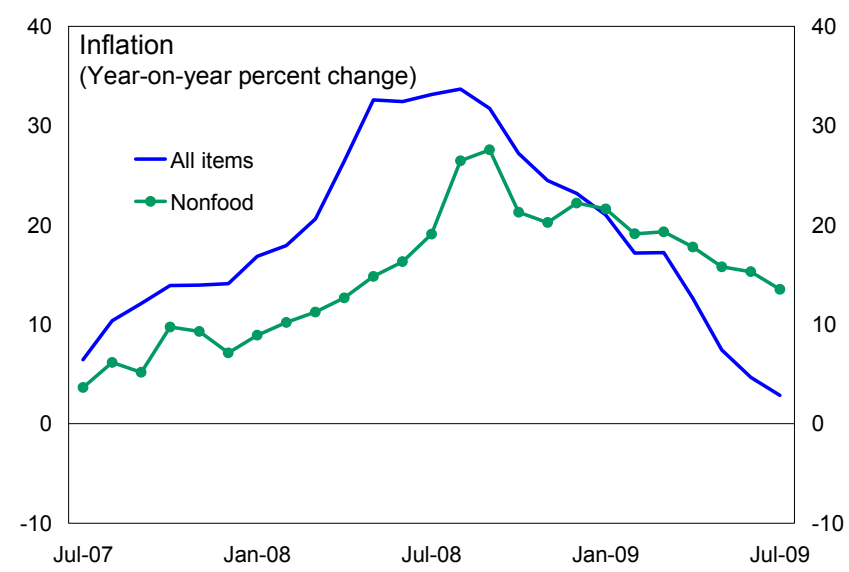

The decline is being driven by manufacturing, especially basic metals that are used as an input to construction.

Mongolia: Real Industrial Production (Contribution to grow th, year-on-year)

\begin{tabular}{lrrrr}
\hline & $\begin{array}{r}\text { 12-month } \\
\text { rolling }\end{array}$ & H1 & Q1 & Q2 \\
\hline Gross Industrial Output & -2.4 & -7.9 & -8.3 & -7.6 \\
Mining and quarrying & 0.6 & -0.9 & -3.3 & 1.2 \\
Manufacturing & -3.4 & -7.3 & -5.6 & -8.7 \\
$\quad$ Food and beverages & 1.1 & 0.1 & 0.1 & 0.1 \\
Textile & 0.6 & -0.6 & 0.3 & -1.4 \\
Basic metals & -5.6 & -6.2 & -5.9 & -6.5 \\
Other & 0.6 & -0.6 & -0.2 & -1.0 \\
Electricity, thermal energy, and w ater supply & 0.4 & 0.2 & 0.6 & -0.1 \\
\hline
\end{tabular}

The decline in real government spending, though expected and unavoidable, is taking its toll on growth.

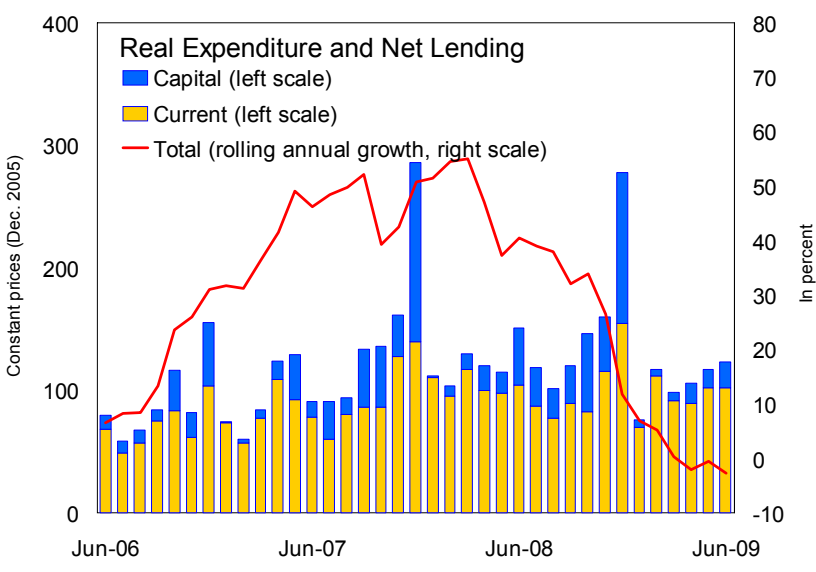

The stock of private credit is still contracting, although there are some preliminary signs that it is bottoming out.

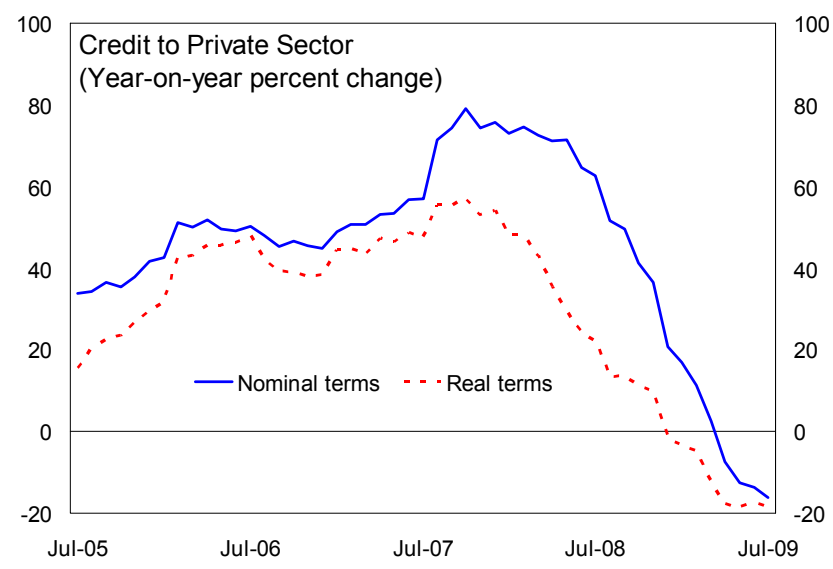

Sources: Mongolian authorities; and IMF staff estimates. 


\section{Figure 2. Market Conditions}

Main Message: Market conditions have stabilized but there is little room for further monetary policy loosening at this stage.

The inflation-induced real appreciation since 2007 has largely been unwound by a nominal depreciation...

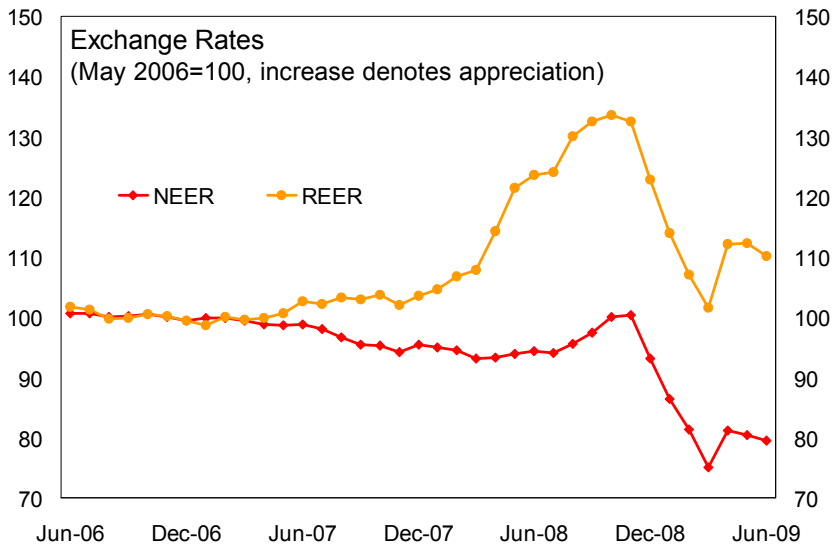

Until recently, the central bank was a net buyer of foreign exchange at the auctions, helping build reserves.

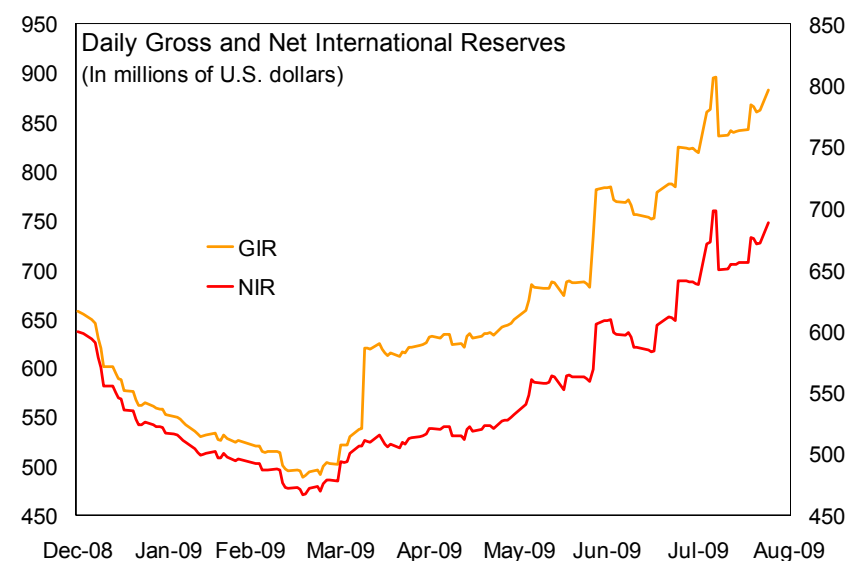

....and a sharp increase in reserve money in June contributed to an easing of monetary conditions.

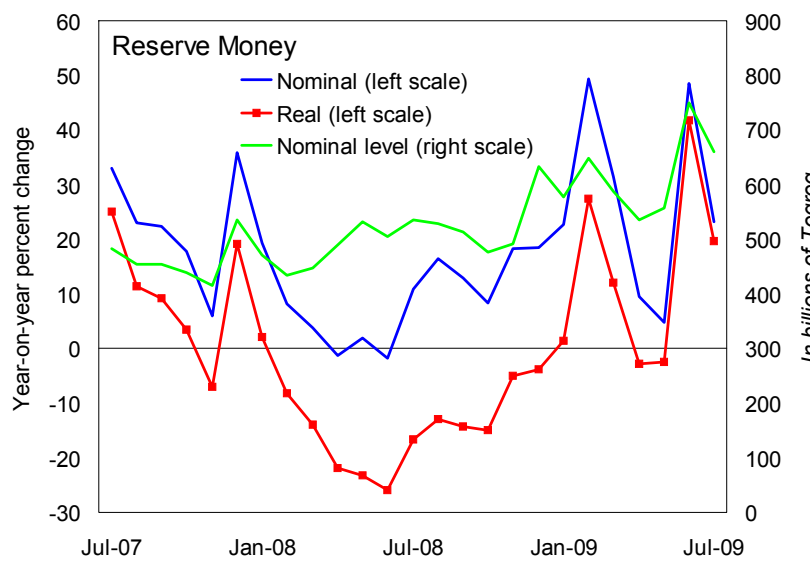

Sources: Mongolian authorities; and IMF staff estimates. ...and the exchange market has stabilized, with the foreign currency auction system working well.

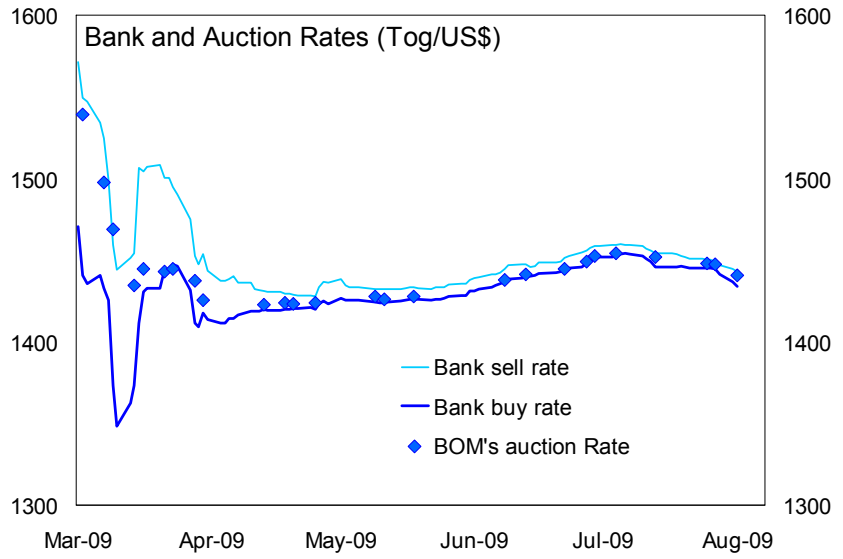

The central bank twice lowered the 7-day CBB interest rate, facilitating an even larger decline in the 12-week rate...

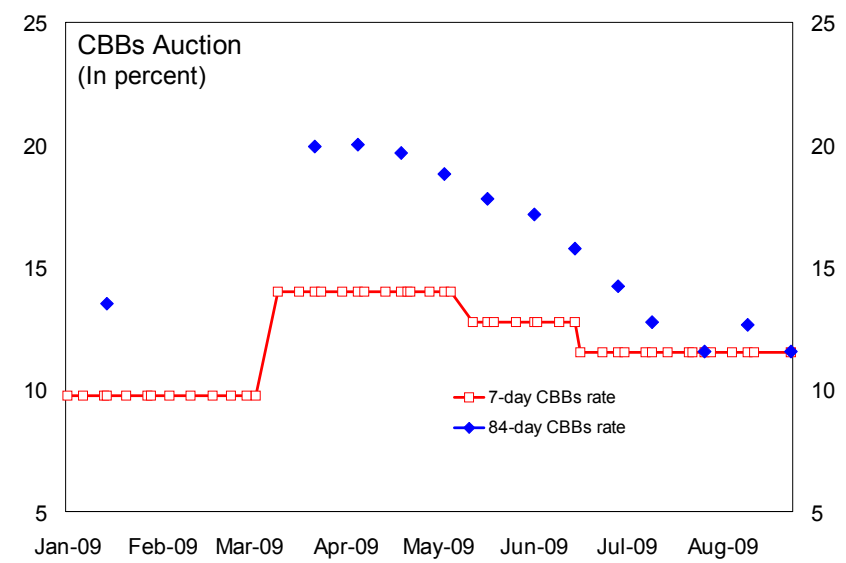

However, broad money growth remains sluggish as the expected remonetization is proceeding slowly.

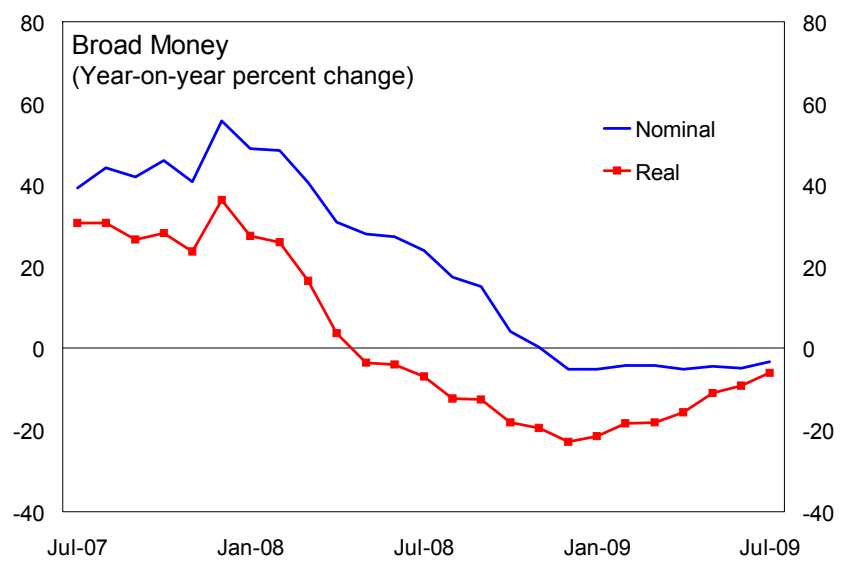


Table 1. Mongolia: Selected Economic and Financial Indicators, 2007-10

Nominal GDP (2008): US $\$ 5,243$ million $1 /$

Population, end-year (2008): 2.68 million

Per capita GDP (2008): US $\$ 1,9562 /$

Poverty incidence (2007/08): 35.2 percent $3 /$

Quota: SDR 51.1 million

\begin{tabular}{|c|c|c|c|c|c|c|}
\hline & \multirow[b]{2}{*}{2007} & \multirow{2}{*}{$\frac{\text { Rev. }}{2008}$} & \multicolumn{2}{|c|}{ Proj. } & \multicolumn{2}{|c|}{ 1st review } \\
\hline & & & 2009 & $\overline{2010}$ & 2009 & 2010 \\
\hline & \multicolumn{6}{|c|}{ (Percent change) } \\
\hline \multicolumn{7}{|l|}{ Real sector } \\
\hline Real GDP growth & 10.2 & 8.9 & 0.5 & 3.0 & 2.7 & 4.3 \\
\hline Mineral & 2.9 & 0.1 & 0.0 & 1.0 & 0.0 & 1.0 \\
\hline Nonmineral & 12.2 & 11.0 & 0.6 & 3.5 & 3.2 & 5.0 \\
\hline Consumer prices (period average) & 8.2 & 26.8 & 8.5 & 7.9 & 10.1 & 7.9 \\
\hline Consumer prices (end-period) & 14.1 & 23.2 & 8.5 & 6.0 & 9.6 & 7.0 \\
\hline \multirow[t]{2}{*}{ GDP deflator } & 12.3 & 22.4 & 0.8 & 8.3 & 0.0 & 9.4 \\
\hline & \multicolumn{6}{|c|}{ (In percent of GDP) } \\
\hline \multicolumn{7}{|l|}{ General government budget } \\
\hline Revenue and grants & 40.9 & 35.4 & 30.8 & 30.1 & 30.8 & 31.6 \\
\hline Expenditure and net lending & 38.0 & 40.2 & 37.3 & 35.0 & 36.8 & 35.6 \\
\hline Current balance & 14.1 & 6.4 & 0.7 & 2.5 & 1.9 & 4.5 \\
\hline Primary balance & 3.2 & -4.5 & -6.0 & -4.1 & -4.7 & -3.8 \\
\hline Overall balance (including grants) & 2.8 & -4.8 & -6.5 & -5.0 & -6.0 & -4.0 \\
\hline \multirow[t]{2}{*}{ Nonmineral overall balance } & -10.6 & -14.9 & -12.1 & -9.0 & -9.9 & -9.1 \\
\hline & \multicolumn{6}{|c|}{ (Percent change) } \\
\hline \multicolumn{7}{|l|}{ Money and credit 4/ } \\
\hline Net foreign assets & 19.1 & -49.3 & 48.1 & 10.6 & 39.1 & 32.5 \\
\hline Net domestic assets & 157.6 & 52.1 & 0.7 & 30.9 & 19.3 & 22.0 \\
\hline Domestic credit & 71.0 & 52.6 & 5.1 & 21.7 & 13.6 & 18.0 \\
\hline Broad money & 55.6 & -5.1 & 15.0 & 23.0 & 25.1 & 25.4 \\
\hline Reserve money & 35.9 & 18.4 & 15.2 & 15.0 & 12.1 & 17.7 \\
\hline Broad money velocity (GDP/BM) & 1.9 & 2.7 & 2.4 & 2.2 & 2.2 & 2.0 \\
\hline \multirow[t]{2}{*}{ Interest rate on central bank bills, end-period (percent) $5 /$} & 8.4 & 9.8 & $\ldots$ & & $\ldots$ & $\ldots$ \\
\hline & \multicolumn{6}{|c|}{ (In millions of US\$) } \\
\hline \multicolumn{7}{|l|}{ Balance of payments } \\
\hline Current account balance (including official transfers) & 265 & -688 & -291 & -449 & -262 & -268 \\
\hline (In percent of GDP) & 6.7 & -13.1 & -6.9 & -10.3 & -6.5 & -6.2 \\
\hline Trade balance & -54 & -613 & -183 & -411 & -201 & -245 \\
\hline Exports & 1,949 & 2,534 & 1,830 & 2,117 & 1,858 & 2,211 \\
\hline Imports & $-2,003$ & $-3,147$ & $-2,013$ & $-2,528$ & $-2,059$ & $-2,457$ \\
\hline Foreign direct investment & 360 & 586 & 517 & 930 & 317 & 330 \\
\hline Gross official international reserves (end-period) 6/ & 1,001 & 657 & 920 & 1,069 & 822 & 1,075 \\
\hline (In months of next year's imports of goods and services) & 3.2 & 3.2 & 3.7 & 3.9 & 3.3 & 3.7 \\
\hline \multicolumn{7}{|l|}{ Trade prices } \\
\hline Export prices (US\$, percent change) & 26.0 & 3.9 & -23.5 & 4.5 & -27.0 & 5.5 \\
\hline Import prices (US\$, percent change) & 9.6 & 19.1 & -19.8 & 6.1 & -25.3 & 4.9 \\
\hline \multirow[t]{2}{*}{ Terms of trade (percent change) } & 15.0 & -12.8 & -4.6 & -1.5 & -2.2 & 0.6 \\
\hline & \multicolumn{6}{|c|}{ (In percent of GDP) } \\
\hline \multicolumn{7}{|l|}{ Public and publicly guaranteed debt } \\
\hline Total public debt & 39.4 & 33.1 & 49.1 & 52.1 & 46.8 & 47.8 \\
\hline Domestic debt $7 /$ & 0.5 & 0.0 & 2.6 & 5.2 & 0.0 & 0.0 \\
\hline External debt $8 /$ & 38.9 & 33.1 & 46.5 & 46.9 & 46.8 & 47.8 \\
\hline (In million US\$) & 1,529 & 1,601 & 1,860 & 2,002 & 1,796 & 2,048 \\
\hline Exchange rate & & & & & & \\
\hline Togrogs per US\$ (end-period) & 1,170 & 1,268 & $\ldots$ & $\ldots$ & $\ldots$ & $\ldots$ \\
\hline Togrogs per US\$ (period average) & 1,170 & 1,169 & $\ldots$ & $\ldots$ & $\ldots$ & $\ldots$ \\
\hline Nominal effective exchange rate (end-period; percent change) & -4.0 & -2.5 & $\ldots$ & $\ldots$ & $\ldots$ & $\ldots$ \\
\hline Real effective exchange rate (end-period; percent change) & 4.1 & 18.7 & $\ldots$ & $\ldots$ & $\ldots$ & $\ldots$ \\
\hline Nominal GDP (billions of togrogs) & 4,600 & 6,130 & 6,209 & 6,931 & 6,294 & 7,180 \\
\hline
\end{tabular}

Sources: Mongolian authorities; and IMF staff projections.

1/ Based on period average exchange rate.

2/ Estimate, based on period average exchange rate.

3/ Based on The Household Socio-Economic Survey 2007-08.

4/ For 2009-10, valued at the program exchange rate and gold price.

5/ Yield of 14-day bills until 2006 and of 7-day bills from 2007 onward.

6/ The projections for 2009 and 2010 include the SDR allocations (general and special) of SDR 48.8 million.

7/ The projections for 2009 and 2010 include the estimated fiscalization cost of the resolution of Anod bank.

$8 /$ Includes prospective Fund credit under the SBA. 
Table 2. Mongolia: Summary Operations of the General Government, 2007-10

\begin{tabular}{|c|c|c|c|c|c|c|}
\hline & \multirow[b]{2}{*}{2007} & \multirow{2}{*}{$\frac{\text { Rev. }}{2008}$} & \multicolumn{2}{|c|}{ Proj. } & \multicolumn{2}{|c|}{ 1st review } \\
\hline & & & 2009 & 2010 & 2009 & 2010 \\
\hline & \multicolumn{6}{|c|}{ (In billions of togrogs) } \\
\hline Total expenditure and net lending & 1,750 & 2,467 & 2,315 & 2,428 & 2,316 & 2,559 \\
\hline Overall balance (incl. grants) & 131 & -296 & -405 & -345 & -380 & -290 \\
\hline Nonmineral overall balance & -486 & -911 & -753 & -622 & -621 & -653 \\
\hline Foreign (net) & 47 & 39 & 303 & 18 & 53 & 150 \\
\hline Domestic (net) & -178 & 258 & 102 & 327 & 101 & 40 \\
\hline \multirow[t]{2}{*}{ Donor support } & 0 & 0 & 0 & 0 & 227 & 100 \\
\hline & \multicolumn{6}{|c|}{ (In percent of GDP) } \\
\hline Total revenue and grants & 40.9 & 35.4 & 30.8 & 30.1 & 30.8 & 31.6 \\
\hline Enterprise income tax & 4.8 & 4.1 & 2.9 & 2.9 & 3.5 & 4.0 \\
\hline Personal income tax & 1.6 & 1.9 & 2.2 & 2.2 & 1.6 & 1.6 \\
\hline "Windfall" tax & 7.7 & 6.3 & 1.8 & 2.4 & 0.9 & 1.2 \\
\hline Social security contributions & 3.5 & 3.7 & 4.3 & 5.0 & 3.9 & 3.9 \\
\hline Sales tax and VAT & 5.8 & 6.0 & 5.5 & 5.5 & 6.2 & 6.0 \\
\hline Excise taxes & 2.9 & 2.9 & 2.7 & 2.7 & 3.2 & 3.6 \\
\hline Customs duties and export taxes & 2.2 & 2.3 & 1.9 & 2.4 & 2.5 & 2.4 \\
\hline Other taxes & 4.2 & 3.6 & 3.3 & 2.6 & 3.4 & 3.6 \\
\hline Nontax revenue & 7.7 & 4.2 & 5.5 & 4.0 & 5.2 & 4.9 \\
\hline Capital revenue and grants & 0.5 & 0.3 & 0.7 & 0.4 & 0.4 & 0.4 \\
\hline Total expenditure and net lending & 38.0 & 40.2 & 37.3 & 35.0 & 36.8 & 35.6 \\
\hline Capital expenditure & 10.0 & 10.2 & 6.9 & 6.5 & 6.7 & 6.7 \\
\hline Domestically-financed & 9.5 & 9.9 & 6.5 & 6.1 & 6.2 & 5.9 \\
\hline Foreign-financed & 0.5 & 0.3 & 0.4 & 0.3 & 0.5 & 0.7 \\
\hline Net lending & 1.7 & 1.3 & 0.9 & 1.3 & 1.6 & 2.3 \\
\hline On-lent foreign project loans & 1.6 & 1.1 & 1.4 & 1.7 & 1.9 & 2.6 \\
\hline Domestic lending minus repayments & 0.2 & 0.3 & -0.5 & -0.3 & -0.3 & -0.3 \\
\hline Current balance (excl. privatization receipts) & 14.1 & 6.4 & 0.7 & 2.5 & 1.9 & 4.5 \\
\hline Primary balance & 3.2 & -4.5 & -6.0 & -4.1 & -4.7 & -3.8 \\
\hline Overall balance (incl. grants) & 2.8 & -4.8 & -6.5 & -5.0 & -6.0 & -4.0 \\
\hline Discrepancy between above and below the line & 0.0 & 0.0 & 0.0 & 0.0 & 0.0 & 0.0 \\
\hline Financing & -2.8 & 4.8 & 6.5 & 5.0 & 6.0 & 4.0 \\
\hline Foreign (net) & 1.0 & 0.6 & 4.9 & 0.3 & 0.8 & 2.1 \\
\hline Disbursements & 2.1 & 1.4 & 6.5 & 1.4 & 2.4 & 3.3 \\
\hline Project loans & 2.1 & 1.4 & 1.8 & 2.0 & 2.4 & 3.3 \\
\hline Program loans & 0.0 & 0.0 & 3.1 & 0.9 & 0.0 & 0.0 \\
\hline Gold financing loan & 0.0 & 0.0 & 1.6 & -1.5 & $\ldots$ & $\ldots$ \\
\hline Amortization & 1.1 & 0.7 & 1.6 & 1.2 & 1.6 & 1.2 \\
\hline Domestic (net) & -3.9 & 4.2 & 1.6 & 4.7 & 1.6 & 0.6 \\
\hline Banking system (net) & -3.8 & 4.1 & 1.3 & 4.4 & 1.3 & 0.6 \\
\hline Nonbank & 0.0 & 0.1 & 0.3 & 0.3 & 0.3 & 0.0 \\
\hline Donor support & 0.0 & 0.0 & 0.0 & 0.0 & 3.6 & 1.4 \\
\hline
\end{tabular}

Sources: Ministry of Finance; IMF and staff projections.

$1 /$ Includes reclassifications between goods and services and transfers starting in 2009, which accounts for about two-thirds of the increase in transfers relative to GDP in 2009.

2/ Includes the estimated fiscalization cost of the resolution of Anod bank. 
Table 3. Mongolia: Monetary Aggregates, 2007-10 1/

\begin{tabular}{|c|c|c|c|c|c|c|c|}
\hline & \multirow[b]{2}{*}{2007} & \multicolumn{2}{|l|}{ Rev. } & \multicolumn{2}{|c|}{ Proj. } & \multicolumn{2}{|c|}{ 1st review 2/ } \\
\hline & & 2008 & June 2009 & 2009 & 2010 & 2009 & 2010 \\
\hline & \multicolumn{7}{|c|}{ (In billions of togrog; end of period) } \\
\hline Broad Money & 2,391 & 2,270 & 2,518 & 2,610 & 3,211 & 2,900 & 3,637 \\
\hline Currency & 283 & 329 & 284 & 378 & 438 & 390 & 489 \\
\hline Deposits & 2,108 & 1,941 & 2,234 & 2,232 & 2,773 & 2,510 & 3,148 \\
\hline Net foreign assets & 1,348 & 683 & 1,030 & 1,013 & 1,120 & 942 & 1,248 \\
\hline Net domestic assets & 1,043 & 1,587 & 1,488 & 1,597 & 2,091 & 1,958 & 2,389 \\
\hline Domestic credit & 1,389 & 2,119 & 2,094 & 2,227 & 2,710 & 2,495 & 2,943 \\
\hline Net credit to government & -703 & -574 & -593 & -330 & -22 & -416 & -376 \\
\hline Claims on nonbanks & 2,092 & 2,692 & 2,686 & 2,557 & 2,732 & 2,910 & 3,319 \\
\hline Other items, net & -346 & -532 & -606 & -630 & -619 & -537 & -554 \\
\hline Reserve money & 535 & 634 & 769 & 730 & 840 & 710 & 836 \\
\hline Net foreign assets & 1,134 & 805 & 1,011 & 1,073 & 1,168 & 1,042 & 1,298 \\
\hline BOM defined reserves $3 /$ & 1,137 & 808 & 1,015 & 1,191 & 1,286 & 1,045 & 1,301 \\
\hline Net international reserves (NIR) 4/ 5/ & $\ldots$ & 628 & 741 & 1,043 & 1,138 & $\ldots$ & $\ldots$ \\
\hline Other BOM defined reserves & $\ldots$ & 180 & 275 & 148 & 148 & $\ldots$ & $\ldots$ \\
\hline Other assets, net $5 /$ & -4 & -3 & -4 & -118 & -118 & -3 & -3 \\
\hline Net domestic assets & -599 & -171 & -243 & -343 & -328 & -332 & -462 \\
\hline Net credit to government & -573 & -183 & -68 & 64 & 114 & -74 & -74 \\
\hline Claims on deposit money banks & 19 & 243 & 153 & 20 & 20 & 165 & 165 \\
\hline Minus: Central bank bills (net) & 103 & 120 & 144 & 225 & 270 & 303 & 475 \\
\hline Other items, net & 59 & -112 & -183 & -202 & -192 & -120 & -78 \\
\hline Memorandum items: & \multicolumn{7}{|c|}{ (In percent; unless otherwise indicated) } \\
\hline Excluding Anod bank's loans & $\ldots$ & $\ldots$ & $\ldots$ & 1.9 & 6.9 & $\ldots$ & $\ldots$ \\
\hline Annual reserve money growth & 35.9 & 18.4 & 52.2 & 15.2 & 15.0 & 12.1 & 17.7 \\
\hline Velocity & 1.9 & 2.7 & 2.5 & 2.4 & 2.2 & 2.2 & 2.0 \\
\hline Broad money/reserve money & 4.5 & 3.6 & 3.3 & 3.6 & 3.8 & 4.1 & 4.3 \\
\hline Total loans/deposits & 99.3 & 138.7 & 120.2 & 114.6 & 98.5 & 116.0 & 105.4 \\
\hline BOM defined reserves (in millions of US\$) 3/ & 972 & 637 & 651 & 764 & 825 & 670 & 834 \\
\hline Net international reserves (NIR, in millions of US\$) 4/ 5/ & $\ldots$ & 495 & 475 & 669 & 730 & 575 & 739 \\
\hline Net credit to government program definition $6 /$ & $\ldots$ & -574 & $\ldots$ & -509 & -202 & $\ldots$ & $\ldots$ \\
\hline
\end{tabular}

Sources: Mongolian authorities; and IMF staff projections.

$1 /$ Valued at the program exchange rate and gold price.

2/ Data as presented in the IMF Country Report 09/130, and, therefore, does not incorporate changes due to a reclassification of government deposits and net international reserves (NIR).

3/ Previously referred to as net international reserves.

4/ Previously referred to as net international reserves under program definition. The definition of NIR has been revised in line with the recommendation of the IMF Safeguard Assessment, and does not include commercial bank foreign currency deposits and foreign currency current accounts held at the Bank of Mongolia. These revisions do not apply to the columns from the IMF Country Report 09/130.

5/ The projections for 2009 and 2010 include the SDR allocations (general and special) of SDR 48.8 million.

6/ Net credit to government excluding government deposits in Anod bank and the cost associated with the resolution of Anod bank. 
Table 4. Mongolia: Balance of Payments, 2007-10

(In millions of US\$, unless indicated otherwise)

\begin{tabular}{|c|c|c|c|c|c|c|c|}
\hline & \multirow[b]{2}{*}{2007} & \multirow{2}{*}{$\frac{\text { Rev. }}{2008}$} & \multicolumn{2}{|c|}{ Proj. } & \multicolumn{3}{|c|}{ 1st review } \\
\hline & & & 2009 & 2010 & 2008 & 2009 & 2010 \\
\hline Current account balance (including official grants) & 265 & -688 & -291 & -449 & -503 & -262 & -268 \\
\hline Trade balance & -54 & -613 & -183 & -411 & -464 & -201 & -245 \\
\hline Exports & 1,949 & 2,534 & 1,830 & 2,117 & 2,667 & 1,858 & 2,211 \\
\hline Copper concentrate & 812 & 836 & 496 & 525 & 836 & 430 & 478 \\
\hline Gold & 235 & 600 & 566 & 733 & 600 & 575 & 727 \\
\hline Other & 903 & 1,099 & 768 & 859 & 1,231 & 853 & 1,006 \\
\hline Imports & $-2,003$ & $-3,147$ & $-2,013$ & $-2,528$ & $-3,131$ & $-2,059$ & $-2,457$ \\
\hline Oil imports & -560 & -891 & -438 & -545 & -966 & -388 & -542 \\
\hline Food imports & -266 & -436 & -328 & -340 & -391 & -273 & -329 \\
\hline Other & $-1,177$ & $-1,820$ & $-1,247$ & $-1,643$ & $-1,774$ & $-1,399$ & $-1,586$ \\
\hline Services, net & 161 & -191 & -207 & -146 & -152 & -266 & -230 \\
\hline Income, net & -79 & -131 & -133 & -134 & -91 & -124 & -135 \\
\hline Current transfers & 237 & 247 & 232 & 242 & 205 & 329 & 342 \\
\hline General government & 133 & 121 & 144 & 147 & 74 & 240 & 230 \\
\hline Other sectors & 104 & 125 & 88 & 95 & 131 & 89 & 112 \\
\hline Of which: workers remittances & 84 & 94 & 58 & 64 & 100 & 50 & 72 \\
\hline Capital and financial account & 236 & 511 & 420 & 509 & 396 & 150 & 373 \\
\hline Direct investment 1/ & 360 & 586 & 517 & 930 & 682 & 317 & 330 \\
\hline Portfolio investment & 75 & -18 & 67 & -141 & -13 & 1 & 1 \\
\hline Trade credits, net & -13 & 72 & -51 & -37 & 72 & -53 & -37 \\
\hline Currency and deposits, net & -268 & -293 & -259 & -245 & -293 & -259 & -245 \\
\hline Loans, net $1 /$ & 45 & 173 & 204 & 358 & 114 & 377 & 441 \\
\hline Other, net & 37 & -9 & -58 & -356 & -167 & -233 & -118 \\
\hline SDR allocations & 0 & 0 & 75 & 0 & 0 & 0 & 0 \\
\hline Errors and omissions & -212 & -161 & 0 & 0 & -231 & 0 & 0 \\
\hline Overall balance & 288 & -338 & 129 & 60 & -338 & -112 & 104 \\
\hline Financing & -288 & 338 & -129 & -60 & 338 & 251 & -12 \\
\hline Gross official reserves (- increase) & -283 & 343 & -263 & -149 & 343 & -165 & -253 \\
\hline Use of IMF credit $(+)$ & -5 & -5 & 134 & 89 & -5 & -6 & -5 \\
\hline Financing need (- overfinancing) & 0 & 0 & 0 & 0 & 0 & 284 & 153 \\
\hline \multicolumn{8}{|l|}{ Memoranda items: } \\
\hline \multicolumn{8}{|l|}{ Current account balance (in percent of GDP) } \\
\hline Including official grants & 6.7 & -13.1 & -6.9 & -10.3 & -9.6 & -6.5 & -6.2 \\
\hline Excluding Oyu Tolgoi & 9.4 & -10.3 & -1.2 & 3.5 & $\ldots$ & $\ldots$ & $\ldots$ \\
\hline Excluding official grants & 3.3 & -15.4 & -10.3 & -13.7 & -11.0 & -12.4 & -11.5 \\
\hline Gross official reserves (end-period) 2/ & 1,001 & 657 & 920 & 1,069 & 657 & 822 & 1,075 \\
\hline (In months of imports of goods and services) & 3.2 & 3.2 & 3.7 & 3.9 & 3.0 & 3.3 & 3.7 \\
\hline (In months of nonmining imports) $3 /$ & 3.7 & 4.0 & 5.4 & 4.2 & 3.4 & 3.7 & 4.2 \\
\hline Copper price (in US\$ per ton) & 7,132 & 6,963 & 4,000 & 4,100 & 6,963 & 3,500 & 3,800 \\
\hline Oil price (in US\$ per barrel) & 71 & 97 & 58 & 70 & 97 & 44 & 52 \\
\hline Gold price (in US\$ per troy oz.) & 697 & 872 & 914 & 986 & 872 & 880 & 890 \\
\hline
\end{tabular}

Sources: Mongolian authorities; and IMF staff projections.

1/ Includes the assumed financing of Oyu Tolgoi project of about $\$ 4$ billion, financed by FDI and loans during 2008-13. The project can be exploited in two stages: open pit section commencing in 2012 and a larger underground reserve in 2015.

2/ The projections for 2009 and 2010 include the SDR allocations (general and special) of SDR 48.8 million.

$3 /$ Nonmining imports of goods and services are approximated by total imports minus foreign direct investment. 
Table 5. Mongolia: Reviews and Disbursements under the 18-month Stand-By Arrangement

\begin{tabular}{|c|c|c|c|}
\hline \multirow[b]{2}{*}{ Date } & \multicolumn{2}{|c|}{ Amount of Purchase } & \multirow[b]{2}{*}{ Condition } \\
\hline & $\begin{array}{l}\text { In percent of } \\
\text { quota }\end{array}$ & In SDRs & \\
\hline April 1, 2009 & 100 & $51,100,000$ & Approved Stand-By Arrangement. \\
\hline June 23, 2009 & 50 & $25,550,000$ & $\begin{array}{l}\text { Completion of the first review and observance of end-April } 2009 \\
\text { performance criteria. }\end{array}$ \\
\hline September 21, 2009 & 30 & $15,330,000$ & $\begin{array}{l}\text { Completion of the second review and observance of end-June } \\
2009 \text { performance criteria. }\end{array}$ \\
\hline December 15, 2009 & 30 & $15,330,000$ & $\begin{array}{l}\text { Completion of the third review and observance of end- } \\
\text { September } 2009 \text { performance criteria. }\end{array}$ \\
\hline March 15, 2010 & 30 & $15,330,000$ & $\begin{array}{l}\text { Completion of the fourth review and observance of end- } \\
\text { December } 2009 \text { performance criteria. }\end{array}$ \\
\hline June 15, 2010 & 30 & $15,330,000$ & $\begin{array}{l}\text { Completion of the fifth review and observance of end-March } \\
2010 \text { performance criteria. }\end{array}$ \\
\hline September 15, 2010 & 30 & $15,330,000$ & $\begin{array}{l}\text { Completion of the sixth review and observance of end-June } \\
2010 \text { performance criteria. }\end{array}$ \\
\hline Total & 300 & $153,300,000$ & \\
\hline
\end{tabular}




\section{ATTACHMENT 1}

September 1, 2009

Mr. Dominique Strauss-Kahn

Managing Director

International Monetary Fund

Washington, D.C. 20431

Dear Mr. Strauss-Kahn:

Mongolia has benefited greatly from the sound economic policies that the government has pursued, supported by the Stand-By Arrangement with the International Monetary Fund. Market conditions have stabilized, we are rebuilding international reserves, and inflation is falling. However, economic activity is slowing more than we had anticipated. As a result, we have adapted our policies to provide greater support to the economy and help protect lower income groups most affected by the downturn.

The attached Memorandum of Economic Policies (MEP) describes the macroeconomic policies for the remainder of 2009 and 2010. Our objective remains to achieve strong, sustainable, and equitable growth with low inflation and our policy priorities are to restore health to public finances, maintain a flexible exchange rate while rebuilding international reserves, bolster confidence in the banking system, and protect the poor.

Given the success to date of the program, and our observance of all end-June program targets, we also request the completion of the second review.

The program will continue to be monitored through quantitative performance criteria and indicative targets, as well as structural benchmarks and quarterly reviews (see Tables 1 and 2 ). The third review is scheduled to take place on or after December 15, 2009 and the fourth review is scheduled to take place on or after March 15, 2010.

We intend to maintain a close policy dialogue with the Fund and stand ready to take additional measures, as appropriate, to ensure the achievement of the government's social and economic objectives under the Stand-By Arrangement. We will consult with the Fund on the adoption of measures, and in advance of revisions to the policies contained in the MEP, in accordance with the Fund's policies on such consultation. Further, we will provide the Fund with such information as it may request on policy implementation and achievement of the program objectives. The government authorizes the IMF to publish this letter and the attached MEP. 
Sincerely yours,

$/ \mathrm{s} /$

S. Bayartsogt

Minister of Finance /s/

L. Purevdorj

Governor of Bank of Mongolia

\section{Attachments}

Memorandum of Economic Policies

Revised Technical Memorandum of Understanding 


\section{Memorandum of Economic Policies}

Our macroeconomic strategy has successfully stabilized market conditions, built international reserves, and lowered inflation. However, the difficult global environment has taken a significant toll on economic growth. Our policies are, as a result, being adapted to the weaker economic circumstances to, insofar as is prudent, provide additional support to the economy and, in particular, those lower income groups most affected by the economic downturn. Quantitative targets and structural policies underlying our program are outlined in Tables 1 and 2.

\section{ConteXt}

1. Macroeconomic outlook. The economy is slowing more than expected. Growth is projected to be around $1 / 2$ percent this year largely as a result of the difficult global environment. The fall in copper prices has caused a sharp decline in export earnings and fiscal revenue necessitating a difficult adjustment in policies to unwind the procyclical policies of the past. The policy path we have chosen, however, is already building the foundation for sustainable growth and low inflation in the coming years. Next year we expect inflation to be maintained in single digits and a recovery to begin in the spring.

\section{Fiscal Policy}

2. Fiscal targets. We are committed to restoring health to public finances. Our targeted fiscal adjustment is ambitious but is being designed in a way that protects the poor and reflects the government's fiscal priorities. In light of the slowing economy, we intend to provide some modest additional support to the economy for this year and next, in line with additional financing sources that we have identified. In particular, we will target a fiscal deficit of $6 \frac{1}{2}$ percent of GDP this year and 5 percent of GDP in 2010.

- $\quad$ For this year we shall accommodate a higher deficit in line with weaker-thanexpected revenues but maintain nominal spending at the levels identified in our budget as amended in March. This will provide support to the economy by avoiding further procyclical spending cuts, facilitate budget execution, and ensure that planned investment can be undertaken before the winter.

- In our 2010 budget, we will undertake a slightly larger adjustment in cyclically adjusted terms by freezing nominal spending on wages and salaries at the 2009 level, comprehensively reforming social transfers, reversing the excise cut on fuel implemented in July, and raising social security contributions. The latter measure will partly unwind the reduction implemented in 2008 and also help reduce the operating deficit in the pension system.

3. Structural fiscal reform. Avoiding the procyclical policies of the past is critical for promoting sustainable growth. We are committed, therefore, to submitting a Fiscal 
Responsibility Law to parliament by the end of this year that aims to promote fiscal transparency, enhance medium-term fiscal planning, and limit the procyclicality of fiscal policy. At the same time, we will also submit a complementary organic budget law to strengthen budget preparation and execution. In addition, we have a plan for comprehensive social transfer reform and intend to pass legislation by end-November. We are committed to safeguarding the poor through improved targeting which will yield fiscal saving through efficiency gains and support our adjustment efforts. We appreciate the donor support in reforming social transfers, and will continue to work with the World Bank and Asian Development Bank to design this reform.

\section{Monetary And Exchange Rate Policies}

4. Exchange rate policy. We are fully committed to a flexible exchange rate to provide a shock absorber against terms of trade volatility and to safeguard international reserves. Our intervention strategy is guided by the goals of achieving our net international reserve (NIR) targets and allowing the exchange rate to move in line with market conditions while smoothing excess volatility due to temporary imbalances. Our twice-weekly foreign exchange auctions are working well and we intend to continue with them for the time being. We will consult with Fund staff on the appropriate policy response if, during any 30 day period, our net sales in the foreign exchange auctions exceed US\$30 million.

5. Monetary policy. Our primary objective for monetary policy continues to be to achieve and maintain low inflation. Our monetary policy framework has been working well and has provided a clear nominal anchor. The Bank of Mongolia (BOM), therefore, will continue to adjust interest rates in line with evolving market conditions to achieve our monetary and NIR targets.

\section{BANKING SYSTEM REFORMS}

6. Strengthening banks. A robust banking system is a top priority of our government. The measures we have already taken - including revising the deposit guarantee system, requiring banks to meet a 12 percent capital adequacy ratio, and enhancing supervisionhave buoyed confidence even as growth has slowed. We will continue to carefully monitor the banking system and stand ready to take further action, as needed. In the period ahead, we will work with the small number of banks that currently do not meet prudential norms to ensure the whole system is compliant with regulatory requirements. In addition, to enhance our supervisory information base, we have also begun an international external audit of all banks.

7. Anod bank. We are committed to resolving Anod bank in a way that is consistent with banking system stability. A foreign investor recently expressed interest in buying the bank. In light of this, we will undertake a due diligence review of the potential purchaser and simultaneously explore other options for resolving the bank. We intend to announce our plan for the bank by end-October. If government financial resources are needed for the resolution, 
the BOM would initially finance the costs to facilitate prompt actions, but we would bring the costs onto the government's fiscal accounts by end-2009 through the issuance of government bonds to the BOM.

\section{OTHER POLICIES}

8. External financing. We are negotiating a swap arrangement with China that will facilitate trade and bolster confidence in our economy. We are also committed to prudently managing any further nonconcessional borrowing within program ceilings and we will maintain the current prohibition on government guarantees.

9. Safeguards assessment. In response to the Fund staff recommendations, we are working with the General Intelligence Agency to grant external auditors access to the vaults and have enhanced the audit oversight of the Supervisory Board.

10. Arrears. We have made progress in settling our arrears to Paris Club creditors, resuming negotiations with Finland, and indicated to Russia our intention to repay part of the debt. We remain committed to resolving the remaining bilateral official arrears. 
Table 1. Mongolia: Quantitative Performance Criteria (PC) and Indicative Targets (IT)

\begin{tabular}{|c|c|c|c|c|c|c|c|c|c|c|}
\hline & \multirow{2}{*}{$\begin{array}{c}12 / 31 / 2008 \\
\text { Actual } \\
\end{array}$} & \multicolumn{3}{|c|}{$6 / 30 / 2009$} & \multicolumn{2}{|c|}{ 9/30/2009 } & \multicolumn{2}{|c|}{$12 / 31 / 2009$} & \multirow{2}{*}{$\begin{array}{l}\text { 3/31/2010 } \\
\text { Prog. }\end{array}$} & \multirow{2}{*}{$\begin{array}{l}\text { 6/30/2010 } \\
\text { Prog. }\end{array}$} \\
\hline & & Prog. & Adjusted & Outcome & Prog. & Rev. Prog. & Prog. & Rev. Prog. & & \\
\hline \multicolumn{11}{|l|}{ Performance criteria 1/ } \\
\hline $\begin{array}{l}\text { Net international reserves (NIR) of the Bank of } \\
\text { Mongolia (BOM) (floor, eop stock, in million US\$) 2/ }\end{array}$ & 495 & 315 & 360 & 475 & 455 & 537 & 575 & 595 & 600 & 535 \\
\hline $\begin{array}{l}\text { Net domestic asset (NDA) of the BOM (ceiling, eop } \\
\text { stock, in billion togrog) } 3 /\end{array}$ & -171 & 14 & -56 & -243 & -195 & -302 & -332 & -343 & -331 & -224 \\
\hline $\begin{array}{l}\text { Net credit to government (NCG) (ceiling, cumulative } \\
\text { from the beginning of the fiscal year, in billion } \\
\text { togrog) } 3 /\end{array}$ & 130 & 156 & 86 & -19 & 72 & -69 & 81 & 64 & 87 & 227 \\
\hline $\begin{array}{l}\text { New nonconcessional external debt maturing in one } \\
\text { year or more, contracted or guaranteed by the } \\
\text { government or the BOM (ceiling, eop stock since } \\
\text { April 2009, in million US\$). }\end{array}$ & 0 & 200 & $\ldots$ & 100 & 200 & 200 & 200 & 200 & 200 & 200 \\
\hline $\begin{array}{l}\text { New nonconcessional external debt maturing in less } \\
\text { than one year, contracted or guaranteed by the } \\
\text { government or the BOM (ceiling, eop stock, in } \\
\text { million US\$). }\end{array}$ & 0 & 0 & $\ldots$ & 0 & 0 & 0 & 0 & 0 & 0 & 0 \\
\hline $\begin{array}{l}\text { Accumulation of domestic payment arrears (ceiling, } \\
\text { eop, in billion togrog). }\end{array}$ & 0 & 0 & $\ldots$ & 0 & 0 & 0 & 0 & 0 & 0 & 0 \\
\hline \multicolumn{11}{|l|}{ Indicative targets } \\
\hline $\begin{array}{l}\text { General government fiscal deficit (ceiling, } \\
\text { cumulative since the beginning of fiscal year, in } \\
\text { billion togrog). }\end{array}$ & 296 & 325 & $\ldots$ & 248 & 290 & 315 & 380 & 405 & 125 & 200 \\
\hline \multicolumn{11}{|l|}{ Memorandum items: } \\
\hline $\begin{array}{l}\text { Support from bilateral and multilateral donors } \\
\text { excluding IMF (cumulative since the beginning of } \\
\text { the year, in million US\$), program level. }\end{array}$ & 0 & 30 & $\ldots$ & 0 & 80 & 112 & 145 & 147 & 20 & 40 \\
\hline $\begin{array}{l}\text { Disbursed new nonconcessional external debt (eop } \\
\text { stock, in million US } \$ \text { ), program level. }\end{array}$ & $\ldots$ & 0 & $\ldots$ & 75 & $\ldots$ & 75 & $\ldots$ & 75 & 75 & 0 \\
\hline
\end{tabular}

$1 /$ Evaluated at the program exchange rate.

2/ NIR does not include commercial bank foreign currency deposits and foreign currency current accounts held at the Bank of Mongolia. The adjustors are specified in the Technical Memorandum of Understanding (TMU), and include: the floor on NIR will be adjusted upward (downward) by the amount of support from bilateral and multilateral donors (excluding IMF) in excess (short) of the program level; the floor will be adjusted upward by the amount of nonconcessional borrowing disbursed in excess of the program level; the floor on NIR will be adjusted upward by the amount of the cumulative additional SDR allocations up to the test date.

3/ The adjustors are specified in the TMU, and include: the ceilings on NDA and NCG, respectively, will be adjusted downward (upward) by the amount of support from bilateral and multilateral donors (excluding IMF) in excess (short) of the program level; the ceilings will be adjusted downward by the amount of nonconcessional debt disbursed in excess of the program level. 
Table 2. Mongolia: Structural Benchmarks

\begin{tabular}{|c|c|c|}
\hline Actions & $\begin{array}{c}\text { Date } \\
\text { 1st review }\end{array}$ & Status \\
\hline Revising relevant laws to require Erdenet to pay taxes in togrog. & $6 / 30 / 2009$ & Completed on July 9. \\
\hline $\begin{array}{l}\text { Establishment of screen-based system for inter-bank foreign exchange } \\
\text { transactions. }\end{array}$ & $6 / 30 / 2009$ & $\begin{array}{l}\text { Not completed. No longer macro- } \\
\text { critical as central bank will continue } \\
\text { to use auctions. }\end{array}$ \\
\hline $\begin{array}{l}\text { Announcement of a resolution plan for Anod bank based on the } \\
\text { diagnostic assessment of the external auditor. }\end{array}$ & $6 / 30 / 2009$ & Delayed to end-October. \\
\hline $\begin{array}{l}\text { A comprehensive review of transfer programs resulting in a revision of } \\
\text { the relevant laws to streamline transfer programs and safeguard the } \\
\text { social safety. }\end{array}$ & $6 / 30 / 2009$ & $\begin{array}{l}\text { Completed late June, reform plan } \\
\text { approved by Cabinet-level Working } \\
\text { Group. }\end{array}$ \\
\hline $\begin{array}{l}\text { Submission to the parliament of a revised banking law and other } \\
\text { pertinent laws and legislations that include: (i) strengthened prompt } \\
\text { corrective action clauses including an increase in penalties for } \\
\text { noncompliance; (ii) requiring consolidated supervision; (iii) an improved } \\
\text { bank resolution framework that more clearly defines the roles of the } \\
\text { conservator and liquidator; (iv) legal protection for bank and nonbank } \\
\text { supervisors; (v) a more clear definition of "group of connected parties;" } \\
\text { and (vi) reinforced prudential supervision requirements. }\end{array}$ & $6 / 30 / 2009$ & Completed on July 24. \\
\hline \multirow[t]{2}{*}{$\begin{array}{l}\text { The submission to parliament of Fiscal Responsibility Law consistent } \\
\text { with recommendations of Fund technical assistance. }\end{array}$} & $12 / 31 / 2009$ & $\begin{array}{l}\text { In progress, FAD provided TA in } \\
\text { July. }\end{array}$ \\
\hline & Date & \\
\hline $\begin{array}{l}\text { Pass a comprehensive social transfer reform that saves money and } \\
\text { protects the poor through better targeting. }\end{array}$ & $12 / 1 / 2009$ & \\
\hline $\begin{array}{l}\text { Pass a } 2010 \text { budget consistent with the IMF supported Stand-By } \\
\text { Arrangement. }\end{array}$ & $12 / 1 / 2009$ & \\
\hline
\end{tabular}




\section{Mongolia-Technical Memorandum of Understanding}

\section{Quantitative Performance Criteria And Indicative Targets}

1. Performance criteria for end-September 2009, end-December 2009, end-March 2010, and end June-2010 have been established with respect to:

- $\quad$ floors on the level of net international reserves of the BOM;

- $\quad$ ceilings on the level of net domestic assets of the BOM;

- $\quad$ ceilings on the level of net bank credit to general government;

- ceilings on the contracting and guaranteeing by the central government or the BOM of new medium- and long-term external debt;

- ceilings on the contracting or guaranteeing by the central government or the BOM of new short-term external debt;

- ceiling on accumulation of domestic payment arrears of the central government.

2. Performance criteria that are applicable on a continuous basis have been established with respect to:

- $\quad$ ceilings on accumulation of new external payment arrears of the central government and the BOM.

3. Indicative targets for end-September 2009, end-December 2009, end-March 2010, and end-June 2010 have been established with respect to:

- $\quad$ ceilings on the general government fiscal deficit.

\section{InSTITUTIONAL DEFINITIONS}

4. The general government includes all units of budgetary central government, social security funds, extrabudgetary funds, and local governments.

5. The domestic banking system is defined as the BOM, the existing and newly licensed commercial banks incorporated in Mongolia and their branches.

\section{Monetary Aggregates}

6. Valuation. Foreign currency-denominated accounts will be valued in togrogs at the program exchange rate between the togrog and the U.S. dollar, Tog 1,560 per U.S. dollar. Foreign currency accounts denominated in currencies other than the U.S. dollar, excluding 
SDRs, will first be valued in U.S. dollars at actual end-of-period exchange rates used by the BOM to calculate the official exchange rates. SDR-denominated accounts will be valued at the program exchange rate of SDR $1=U S \$ 1.509$. Monetary gold will be valued at US\$880 per ounce.

\section{A. Reserve Money}

7. Reserve money consists of currency issued by the BOM (excluding BOM holdings of currency) and commercial banks' deposits held with the BOM.

\section{B. Net International Reserves of the BOM}

8. A floor applies to the level of net international reserves (NIR) of the BOM. The floor on NIR will be adjusted upward (downward) by the amount of support from bilateral and multilateral donors (excluding IMF) in excess (short) of the programmed level. The floor on NIR will also be adjusted upward by the amount of nonconcessional borrowing disbursed in excess of the program level, with the exception of any amounts drawn under a swap arrangement with China. In case that Mongolia participates in any SDR allocation(s), the floor on NIR will be adjusted upward by the amount of the cumulative additional SDR allocations up to the test date.

9. NIR will be calculated as gross international reserves less international reserve liabilities. For program monitoring purposes, the stock of foreign assets and foreign liabilities of the BOM shall be valued at program exchange rates and gold price as described on paragraph 6 above.

10. Gross international reserves of the BOM are defined as the sum of

- monetary gold holdings of the BOM;

- $\quad$ holdings of SDRs;

- $\quad$ Mongolia's reserve position in the IMF;

- $\quad$ foreign currency assets in convertible currencies held abroad that are under the direct and effective control of the BOM and readily available for intervention in the foreign exchange market, or the direct financing of balance of payments imbalances and are of investment grade or held with an investment-grade institution;

- $\quad$ excluded from the definition of gross reserves are capital subscriptions in international institutions, assets in nonconvertible currencies, and gross reserves that are in any way encumbered or pledged, including, but not limited to, reserve assets used as collateral or guarantee for third-party external liabilities. 
11. International reserve liabilities of the BOM are defined as the sum of

- $\quad$ all outstanding liabilities of Mongolia to the IMF;

- $\quad$ any foreign convertible currency liabilities of the BOM to nonresidents with an original maturity of up to and including one year;

- $\quad$ commercial bank foreign currency deposits held at the BOM, commercial bank foreign currency current accounts held at the BOM, any foreign currency claims on residents.

\section{Net Domestic Assets of the BOM}

12. A ceiling applies to the level of net domestic assets (NDA) of the BOM. The ceiling on NDA will be adjusted downward (upward) by the amount of support from bilateral and multilateral donors (excluding IMF) in excess (short) of the programmed level. The ceiling on NDA will be adjusted downward by the amount of nonconcessional debt disbursed during the program period, with the exception of any amounts drawn under a swap arrangement with China.

13. NDA will be calculated as the difference between reserve money and the sum of NIR and other net foreign assets (ONFA) of the BOM.

14. ONFA is defined as the sum of (i) BOM's monetary gold pledged as collateral for external loans to domestic private companies and (ii) other net foreign assets of the BOM, including the difference between accrued interest receivables on gross international reserves of the BOM and accrued interest payables on international reserve liabilities of the BOM and deposits of international financial institutions.

\section{Net Domestic Credit to the General Government}

15. A ceiling applies to the net bank credit flows to the general government (NCG) measured cumulatively from the beginning of the year. The ceiling on NCG will be adjusted downward (upward) by the amount of support from bilateral and multilateral donors (excluding IMF) in excess (short) of the programmed level. The ceiling will also be adjusted downward by the amount of nonconcessional debt disbursed during the program period.

16. NCG is defined as the sum of (i) net borrowing from the BOM (ways and means advances, loans, holdings of restructuring bonds, holdings of treasury bills and other government bonds, and the government liabilities to the IMF minus deposits); (ii) net borrowing from commercial banks (loans, advances, holdings of restructuring bonds, and holdings of treasury bills and other government bonds minus deposits); and (iii) net change in domestic government debt held by parties other than the BOM and commercial banks. NCG 
excludes government deposits lost or government debt (or other liabilities) issued to pay for the resolution of Anod bank.

\section{Fiscal Aggregates}

\section{A. Fiscal Deficit}

17. An indicative ceiling target applies to the general government fiscal deficit measured cumulatively from the beginning of the year.

18. Fiscal deficit is defined as total general government revenue and grants minus total general government expenditure and net lending. The principal costs of resolving Anod bank are excluded from expenditure and net lending, but the corresponding interest payments are included.

\section{Domestic Payment Arrears}

19. Domestic payment arrears for the purpose of the program are measured on the basis of the stock of government payables and liabilities that exceed its due-for-payment date by more than 60 days. If this stock is equal or smaller than Tog 3.5 billion, the program considers domestic arrear accumulation to be zero. If this stock exceeds Tog 3.5 billion, the difference is considered to constitute domestic arrear accumulation. The program aims for zero domestic arrear accumulation under this definition. Overdue claims that are arrears under the definition of the performance criteria subject to litigation shall be excluded from the application of the performance criteria.

\section{EXTernal DebT}

\section{A. Medium- and Long-Term External Debt}

20. A ceiling applies to the contracting and guaranteeing by the central government, the $\mathrm{BOM}$, or other agencies on behalf of the central government of new nonconcessional borrowing debt with nonresidents with original maturities one year or more. The ceiling applies to debt and commitments contracted or guaranteed for which value has not yet been received. However, with respect to swap arrangements with People's Bank of China, only amounts actually drawn under such arrangement would count toward the ceiling and all such drawings, regardless of the duration, would be considered to have an original maturity of more than one year.

21. The definition of debt, for the purposes of the program, is set out in Executive Board Decision No. 12274, Point 9, as revised on August 24, 2000 (see Annex I).

22. Excluded from the ceiling are (i) the use of Fund resources; (ii) lending from the World Bank, the Asian Development Bank, and the International Fund for Agricultural 
Development; (iii) debts incurred to restructure, refinance, or prepay existing debts, to the extent that such debt is incurred on more favorable terms than the existing debt;

(iv) concessional debts; and (vi) any togrog-denominated treasury bill and government bond holdings by nonresidents.

23. For program purposes, the guarantee of a debt arises from any explicit legal obligation of the central government, the BOM, or other agencies on behalf of the central government to service a loan in the event of nonpayment by the recipient (involving payments in cash or in kind), or indirectly through any other obligation of the central government, the BOM, or other agencies on behalf of the central government to finance a shortfall incurred by the loan recipient.

24. For program purposes, a debt is concessional if it includes a grant element of at least 35 percent, calculated as follows: the grant element of a debt is the difference between the net present value (NPV) of debt and its nominal value, expressed as a percentage of the nominal value of the debt. The NPV of debt at the time of its contracting is calculated by discounting the future stream of payments of debt service due on this debt. The discount rates used for this purpose are the currency specific commercial interest reference rates (CIRRs), published by the Organization for Economic Cooperation Development (OECD). For debt with a maturity of at least 15 years, the ten-year-average CIRR will be used to calculate the NPV of debt and, hence, its grant element. For debt with a maturity of less than 15 years, the six-month average CIRR will be used. To both the ten-year and six-month averages, the same margins for differing repayment periods as those used by the OECD would continue to be added $(0.75$ percent for repayment periods of less than 15 years, 1 percent for 15 to 19 years, 1.15 percent for 20 to 29 years, and 1.25 percent for 30 years or more). Loans provided by a private entity will not be considered concessional unless accompanied by a grant or grant element provided by a foreign official entity, such as both components constitute an integrated financing package with a combined grant element equal to at least 35 percent.

\section{B. Short-Term External Debt}

25. A ceiling applies to the contracting and guaranteeing by the central government, the $\mathrm{BOM}$, or other agencies on behalf of the central government of new nonconcessional borrowing debt with nonresidents with original maturities of less than one year. The ceiling applies to debt and commitments contracted or guaranteed for which value has not yet been received.

26. For program purposes, the definition of debt is set out in Executive Board Decision No. 12274, Point 9, as revised on August 24, 2000 (see Annex I).

27. Excluded from the ceiling are (i) debts classified as international reserve liabilities of the BOM; (ii) debts to restructure, refinance, or prepay existing debts; (iii) togrogdenominated treasury bills, government bonds, and BOM bills held by nonresidents; (iv) normal import financing; and (v) amounts drawn under any swap arrangements with 
People's Bank of China. A financing arrangement for imports is considered to be "normal" when the credit is self-liquidating.

\section{External Payment Arrears}

28. A continuous performance criterion applies to the nonaccumulation of external payments arrears on external debt contracted or guaranteed by the general government or the BOM. External payments arrears consist of external debt-service obligations (principal and interest) that have not been paid at the time they are due, as specified in the contractual agreements. However, overdue debt and debt service obligations that are in dispute will not be considered as external payments arrears for the purposes of program monitoring.

\section{DAta Provision}

29. The authorities have committed to using the best available data, so that any subsequent data revisions will not lead to a breach of a performance criterion. All revisions to data will be promptly reported to the Fund's Resident Representative. The likelihood of significant data changes, including definitional changes, will be communicated to Fund staff as soon as the risk becomes apparent to the authorities.

30. Data required to monitor performance under the program, including those related to performance criteria and indicative targets will be provided electronically or in hard copy to the Fund's Resident Representative by the 20th day of each month, unless otherwise indicated. The data to be reported are listed below, and the reporting responsibilities are indicated in parentheses.

\section{A. Monetary Data (BOM)}

- The monetary survey, the balance sheet of the BOM, and the consolidated balance sheet of the commercial banks. Data will be provided on a monthly basis, with the exception of the balance sheet of the BOM, which will be provided on a weekly basis within five working days of the end of the respective week.

- Net international reserves and interventions of the BOM in the foreign exchange market on daily basis.

- Interest rates and volume on standing facilities and market operations on a weekly basis within five working days of the end of the respective week.

- A detailed breakdown of net credit to government from the BOM and the commercial banks.

- $\quad$ Stock of monetary gold in both thousands of fine troy ounces and U.S. dollars. If the BOM engages in monetary gold transactions or employs any other accounting rate, 
directly or implicitly, for valuing gold assets, this information will be reported to the Fund. Any increase in monetary gold through purchases from domestic sources and refining of nonmonetary gold held or purchased by the BOM will also be reported (both prices and volumes). Any liabilities that are guaranteed or otherwise backed by gold will be reported to the Fund.

- A detailed breakdown of "other items net" for both the BOM and the commercial banks, including, inter alia, all valuation changes in net international reserves and net other foreign assets arising from exchange rate changes and/or revaluation of gold.

- $\quad$ Outstanding balances of all deposit accounts of the general government in commercial banks, including those of the extrabudgetary funds.

- $\quad$ Outstanding balances of any new deposit accounts of the general government opened in addition to the existing ones for grants and loans received from multilateral or bilateral donors, including associated counterpart funds.

- A bank-by-bank list of required reserves and actual reserves.

- Results of each central bank bills auction within five working days of each auction, including amount of bills offered, amount demanded, amount sold to each bank, announced rates, and cut-off rates.

\section{B. Fiscal Data (Ministry of Finance (MOF))}

- $\quad$ Consolidated accounts of the central, local, and general government, including detailed data on tax, nontax, and capital revenues, current and capital expenditures, net lending, and financing. Financing components should be separated into foreign sources (cash, project, and program loans) and domestic sources (bank and nonbank).

- $\quad$ Classified transactions of all social insurance funds.

- $\quad$ Domestic payment arrears of the general government.

- $\quad$ Noninterest outstanding payables by each subsector of the general government, including the social security funds, with a detailed breakdown by major categories and remaining maturity.

- Results of each treasury bills auction within five working days of each auction, including amount of bills offered, amount demanded, amount sold to each bank and nonbanks, and the average yield in percent per month. 


\section{External Sector Data (BOM and MOF)}

- $\quad$ Complete list of new contracts for the execution of public investment projects, which have been signed or are under negotiation with foreign or domestic entities, including details on the amounts, terms, and conditions of current or future debt or nondebt obligations arising from these contracts.

- $\quad$ Outstanding stock, disbursements, amortization, and interest payments of short-term external debt contracted or guaranteed by the government or the BOM by creditor in original currency and U.S. dollars.

- $\quad$ Outstanding, disbursements, amortization, and interest payments of medium- and long-term external debt contracted or guaranteed by the government or the BOM by creditor in original currency and U.S. dollars.

- Daily midpoint exchange rates of the togrog against the U.S. dollar, including the official, interbank, and parallel market exchange rates (BOM).

- Arrears on the external debt contracted or guaranteed by the government or the BOM by creditor in original currency and U.S. dollars.

\section{Other Data (National Statistical Office (NSO))}

- $\quad$ The monthly consumer price index and a detailed breakdown by major categories of goods and services included in the consumer basket.

- The NSO's monthly statistical bulletin, including monthly export and import data. 


\section{Annex 1. Guidelines on Performance Criteria with Respect to Foreign DebT}

Excerpt from Executive Board Decision No. 12274, as revised on August 24, 2000

9. (a) For the purpose of this guideline, the term "debt" will be understood to mean a current, i.e., not contingent, liability, created under a contractual arrangement through the provision of value in the form of assets (including currency) or services, and which requires the obligor to make one or more payments in the form of assets (including currency) or services, at some future point(s) in time; these payments will discharge the principal and/or interest liabilities incurred under the contract. Debts can take a number of forms, the primary ones being as follows:

(i) loans, i.e., advances of money to the obligor by the lender made on the basis of an undertaking that the obligor will repay the funds in the future (including deposits, bonds, debentures, commercial loans and buyers' credits) and temporary exchanges of assets that are equivalent to fully collateralized loans under which the obligor is required to repay the funds, and usually pay interest, by repurchasing the collateral from the buyer in the future (such as repurchase agreements and official swap arrangements);

(ii) suppliers' credits, i.e., contracts where the supplier permits the obligor to defer payments until some time after the date on which the goods are delivered or services are provided; and

(iii) leases, i.e., arrangements under which property is provided which the lessee has the right to use for one or more specified period(s) of time that are usually shorter than the total expected service life of the property, while the lessor retains the title to the property. For the purpose of the guideline, the debt is the present value (at the inception of the lease) of all lease payments expected to be made during the period of the agreement excluding those payments that cover the operation, repair or maintenance of the property.

(b) Under the definition of debt set out in point 9 (a) above, arrears, penalties, and judicially awarded damages arising from the failure to make payment under a contractual obligation that constitutes debt are debt. Failure to make payment on an obligation that is not considered debt under this definition (e.g., payment on delivery) will not give rise to debt. 
Press Release No. 09/316

International Monetary Fund

FOR IMMEDIATE RELEASE

Washington, D.C. 20431 USA

September 21, 2009

\section{IMF Executive Board Completes Second Review Under Stand-By Arrangement with Mongolia and Approves US\$24.2 Million Disbursement}

The Executive Board of the International Monetary Fund (IMF) today completed the second review of Mongolia's economic performance under a program supported by an 18-month Stand-By Arrangement (SBA). The completion of the review enables the immediate disbursement of an amount equivalent to SDR 15.33 million (about US\$24.2 million), bringing total disbursements under the arrangement to an amount equivalent to SDR 91.95 million (about US\$145.7 million).

The SBA was approved on April 1, 2009 (see Press Release No. 09/110) for an amount equivalent to SDR 153.3 million (about US\$242.9 million) or 300 percent of Mongolia's quota.

Following the Executive Board's discussion on Mongolia, Mr. Takatoshi Kato, Deputy Managing Director and Acting Chair, stated:

“The Mongolian authorities' strong policy implementation, which supported the stabilization of market conditions and reduction in inflation, is encouraging. Since Mongolia's economic recovery will likely be slower than previously expected due to a stronger-than-projected external shock, policy targets have been recalibrated to provide greater fiscal support to the economy.

"The government is committed to restoring health to public finances, and the fiscal restraint to date is commendable. The fiscal deficit targets for this year and next have been loosened modestly, which will provide more support to the economy and allow automatic stabilizers to operate. The government's fiscal adjustment program remains appropriately ambitious, especially given the limited availability of financing, and is backed by structural reforms to strengthen the effectiveness of fiscal policy. Key in this regard are the plans to pass a comprehensive social transfer reform that better targets the poor and to adopt a Fiscal Responsibility Law to strengthen fiscal management and contain procyclicality.

"The authorities' monetary and exchange rate policy has been instrumental in stabilizing financial markets and lowering inflation. Rebuilding international reserves and allowing the exchange rate to adjust flexibly in line with market conditions are key for bolstering the economy's resilience to shocks. The central bank therefore should confine the sale of foreign 
exchange to preventing sharp movements in the exchange rate, while adjusting interest rates in line with market conditions to maintain low and stable inflation.

"Strengthening the banking system remains a top priority, which includes pressing ahead with the planned international external audit of all banks and the prompt resolution of Anod Bank. The steps the central bank has taken to enhance supervision and bolster confidence are welcome, as is its commitment to carefully monitor the banking system and take further actions if needed.

"In the period ahead, the Mongolian economy stands to benefit considerably from its significant mineral deposits. It is important, therefore, to press ahead with agreements in the mining sector and to strengthen institutions needed to effectively manage this mineral wealth," Mr. Kato stated. 


\section{Statement by Hi-Su Lee, Executive Director for Mongolia and Ji-sung Moon, Advisor to the Executive Director September 21, 2009}

\section{Introduction}

1. The Mongolian authorities wish to express their utmost appreciation to the Fund and staff for their cooperation. The global crisis has had a worse-than-expected impact on economic growth. However, considering the successful achievements in the face of the global crisis, such as the stabilized market conditions, increased international reserves, and lowered inflation rate, we must mention that Mongolia has benefited greatly from the StandBy-Arrangement (SBA). As reflected in the Memorandum of Economic Policies (MEP), my authorities are fully aware of the challenges in the period ahead and stand ready to undertake any measures in close consultation with the Fund.

2. Thanks to the authorities' strong policy implementation, all the end-June Performance Criteria for the second review were successfully met. However, economic growth is slowing more than expected, and there was broad agreement between staff and the authorities to revise the macroeconomic framework. Consequently, the policies were adapted with a view to providing additional support to the economy, as well as to lower income groups most affected by the economic slowdown. The revised policies aim to strike a balance between the need for supporting economic growth and that for continuing fiscal adjustment. We believe that the revised policies will successfully build the foundation for sustainable growth and low inflation in the coming year.

\section{Fiscal Policy}

3. It is highly commendable that, notwithstanding the weak revenue, the authorities have restrained expenditure through end-June and successfully contained the fiscal deficit consistent with the Fund program. We also share staff's judgment that the worse-thanexpected economy is requiring further stimulus support through relaxation of the fiscal deficit target. Restoring health to public finance, however, is also one of the top priorities. We must highlight the authorities' commitment to achieving a fiscal adjustment by freezing nominal spending on wages and salaries at the 2009 level, comprehensively reforming social transfers, reversing the excise tax cut on fuel that was implemented in July, and raising social security contributions in 2010, which are in line with recommendations from FAD's technical assistance.

4. Moreover, structural fiscal reforms will also play an important role in bolstering fiscal credibility and improving public finances. A new Fiscal Responsibility Law and an organic budget law, which will be passed this year and effective from the 2011 budget, aim to promote fiscal transparency, enhance medium-term fiscal planning, and limit the procyclicality of fiscal policy. The planned comprehensive social transfer reform, which will be passed by end-November, is mainly to consolidate the number of social benefits to less than 20. This is an important step forward that will generate fiscal savings through efficiency and protect the poor through better targeting. In this regard, we appreciate the donor support 
provided so far in reforming social transfers. Cooperation with the World Bank and the Asian Development Bank to design this reform should continue.

5. In spite of the additional fiscal stimulus, Mongolia has a bright fiscal outlook. Copper is currently priced at more than US $\$ 6,000$ per ton compared with US $\$ 3,500$ per ton assumed in the original program. Negotiations for large mining projects are progressing well. For example, the authorities reached an agreement with Rio Tinto-Ivanhoe to develop Oyu Tolgoi mine, and the domestic process has been successfully executed. My Authorities are hopeful that this OT agreement could be finalized in the near future. There is no doubt that this agreement would work as a key growth engine of the Mongolian economy.

\section{Monetary and Exchange Rate Policies}

6. The current monetary framework has been working well and has provided a clear nominal anchor. Monetary policy needs to be in line with evolving economic and market conditions to achieve low inflation and international reserve targets. Further interest rate cuts could be considered in close consultation with the Fund.

7. The Mongolian authorities support the need to keep the exchange rate flexible, allowing the exchange rate to move broadly in line with market conditions. Interventions will only be used to avoid large day-to-day exchange rate movements or to build international reserves. Fortunately, the twice-weekly foreign exchange auctions have been working well so far, and thus they will be maintained for the time being. At the same time, the authorities had already developed a screen-based system for interbank FX transactions in March but, following advice from the Fund, they are upgrading the existing screen-based system to serve as the main trading platform for the interbank foreign exchange market.

\section{Banking Sector}

8. With regard to ANOD bank, the authorities intended to announce a resolution plan in August, when a foreign investor expressed interest in buying it. Given the significance of the ANOD bank issue to the Mongolian economy, it should be resolved very carefully and in a manner that is consistent with banking system stability. A due diligence review of the potential purchaser and its guarantor is currently being undertaken and we therefore note the need to delay the announcement of a resolution plan to end-October.

9. A robust banking system is a top priority for Mongolia. Given the fact that the slowing economy is impacting banks, continued monitoring of, and support for, financial system stability is becoming increasingly important. As indicated in the MEP, my authorities are stepping up their endeavors to monitor the banking system. For the purpose of developing a broader and more proactive restructuring scheme, an international external audit of all banks has already been launched with the assistance of the World Bank. The central bank has received capital reinforcement plans for all banks that are currently below the $12 \%$ capital adequacy ratio. Furthermore, new banking and Central Bank laws were drafted and submitted to parliament in July. These laws will help bolster the legal framework for the banking system and reinforce prudential supervision. 


\section{Other issues}

10. Regarding the swap arrangement with China, this arrangement has not been signed yet, which is consistent with the authorities' previous commitment not to sign it until the Fund ensures its compliance with Article VIII obligations. We respect staff's recent determination that this condition had been met and, accordingly, the arrangement will be signed soon. However, the authorities will continue to keep staff informed on any major changes in the swap agreement to enable a reassessment of any possible Article VIII violations.

\section{Conclusion}

11. My authorities are committed to maintaining a close policy dialogue with the Fund and stand ready to take additional measures, if needed, to accomplish the government's social and economic objectives under the SBA. Given the success of the program to date, the observance of the end-June program targets, and the authorities' strong determination to continue to implement the program, we request the completion of the second review.

12. Finally, we reiterate the Mongolian authorities' wish to express their special appreciation to the Fund and its staff for their timely and appropriate policy advice during the unraveling economic crisis. 